\title{
Osteology of a forelimb of an aetosaur Stagonolepis olenkae (Archosauria: Pseudosuchia: Aetosauria) from the Krasiejów locality in Poland and its probable adaptations for a scratch- digging behavior
}

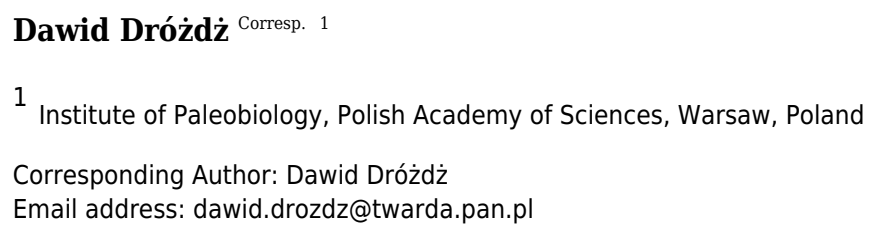

Aetosaurs are armored basal archosaurs that played a significant role in land ecosystems during the Late Triassic (237-201 Ma). The polish species Stagonolepis olenkae Sulej, 2010 described from the Krasiejów locality (southern Poland) is one of the oldest known representatives of the group. Abundant and well-preserved material, including partially articulated specimens, allows a detailed description of the forelimbs in this species. The forelimbs of Stagonolepis olenkae are the most similar to that of large aetosaurs like Desmatosuchus smalli, Desmatosuchus spurensis, Longosuchus meadei, Typothorax coccinarum or Stagonolepis robertsoni. Several characters recognized in the forelimbs of Stagonolepis olenkae suggest its adaptation for scratch-digging. The most salient of these features are: short forearm, carpus, and hands, with the radius shorter than the humerus, carpus and manus shorter than the radius (excluding terminal phalanges); a prominent deltopectoral crest that extends distally on the humerus and a wide prominent entepicondyle, a long olecranon process with well-marked attachment of triceps muscle; hooked, laterally compressed, claw-like terminal phalanges with ornamentation of small pits (indicative of well-developed keratin sheaths). Stagonolepis olenkae might have used its robust forelimbs to break through the compacted soil with its claws and proceed to dig in search of food in softened substrate with the shovel-like expansion at the tip of its snout. The entire forelimb of Stagonolepis olenkae is covered by osteoderms, including the dorsal surface of the hand, which is unusual among aetosaurs and have not been noted for any species up to date. 


\section{Osteology of a forelimb of an aetosaur Stagonolepis olenkae}

\section{2 (Archosauria: Pseudosuchia: Aetosauria) from the Krasiejów}

\section{3 locality in Poland and its probable adaptations for a scratch-digging \\ 4 behavior}

5 By DAWID DRÓŻDŻ ${ }^{*}$

$6 \quad{ }^{1}$ Institute of Paleobiology, Polish Academy of Sciences, Poland

7 *e-mail-dawid.drozdz@twarda.pan.pl

\section{Abstract}

9 Aetosaurs are armored basal archosaurs that played a significant role in land ecosystems during the Late Triassic (237-201 Ma). The polish species Stagonolepis olenkae Sulej, 2010 described from the Krasiejów locality (southern Poland) is one of the oldest known representatives of the group. Abundant and well-preserved material, including partially articulated specimens, allows a detailed description of the forelimbs in this species. The forelimbs of Stagonolepis olenkae are the most similar to that of large aetosaurs like or Stagonolepis robertsoni. Several characters recognized in the forelimbs of Stagonolepis olenkae suggest its adaptation for scratch-digging. The most salient of these features are: short forearm, carpus, and hands, with the radius shorter than the humerus, carpus and manus shorter than the radius (excluding terminal phalanges); a prominent deltopectoral crest that extends distally on the humerus and a wide prominent entepicondyle, a long olecranon process with well- 
marked attachment of triceps muscle; hooked, laterally compressed, claw-like terminal phalanges with ornamentation of small pits (indicative of well-developed keratin sheaths). Stagonolepis olenkae might have used its robust forelimbs to break through the compacted soil with its claws and proceed to dig in search of food in softened substrate with the shovel-like expansion at the tip of its snout. The entire forelimb of Stagonolepis olenkae is covered by osteoderms, including the dorsal surface of the hand, which is unusual among aetosaurs and have not been noted for any species up to date.

\section{Introduction}

Aetosaurs are heavily armored, quadrupedal basal archosaurs cladistically nested within Pseudosuchia, the crocodile lineage of archosaurs (e.g. Brusatte et al. 2010; Nesbitt 2011; Desojo et al. 2012, 2013). They are medium to large sized animals (1-6 m long) with semi-erect to erect gait (Parrish 1986; Desojo and Baéz 2005; Desojo and Vizcaíno 2009; Heckert et al. 2010; Padian et al. 2010; Desojo et al. 2013). Their most characteristic feature is the suit of dermal armor composed of rectangular, plate-like osteoderms, which cover the dorsal and partially the lateral surfaces of their bodies, and in more heavily armored species also the belly, ventral surfaces of the tail and the limbs (e.g., Walker 1961; Heckert and Lucas, 2000; Desojo et al. 2013). Presumably, the aetosaurs are considered to be omnivores but their exact mode of life is not clear yet. In most species (with the exception of Aetosaurus ferratus) the triangular skull is equipped with a shovel-like expansion at the tip of tapering snout (e.g., Desojo and Vizcaíno 2009; Sulej 2010; Desojo et al. 2013). They probably used this shovel-like expansion to dig their food out of the ground (e.g., Walker 1961; Sulej 2010; Desojo et al. 2013), likely utilizing limbs in the process (Heckert et al. 2010). Aetosaur fossil remains are restricted in occurrence to the 
43 continental Upper Triassic (Carnian-Rhaetian) (e.g., Heckert and Lucas 2000; Desojo et al.

44 2013). They are known from several localities in Europe, India, Africa, and both Americas,

45 which makes them one of the most widespread groups among pseudosuchians in the Late

46 Triassic (e.g., Desojo et al. 2013).

47 In Poland, aetosaurs have been reported from two localities in southern part of the country:

48 Krasiejów and Poręba. The material described from Poręba is restricted to few osteoderms and a

49 vertebra, which hampers further studies and attempts of taxonomical affiliations (Sulej et al.

50 2012). In contrast, the aetosaur collection from Krasiejów is very rich and provides several

51 cranial and numerous postcranial specimens of different size and probably different ontogenetic

52 age. Although the material is so abundant, there is some controversy over its taxonomical

53 affiliation. In the detailed description of the skull by Sulej (2010), the aetosaur from Krasiejów

54 has been recognized as a new species, Stagonolepis olenkae Sulej, 2010, similar to Stagonolepis

55 robertsoni Agassiz, 1844 from Elgin, Scotland. Further work by Książkiewicz (2014) on the

56 postcranium of the Krasiejów species also supported this thesis. However, Antczak (2015)

57 suggested synonymy of $S$. olenkae and $S$. robertsoni based on new skull material. He argued that

58 previously recognized differences represent intraspecific variations or sexual dimorphism. Quite

59 different results were shown by the cladistic analysis by Parker $(2016,2018)$, also based on the

60 cranial material. It placed S. olenkae and S. robertsoni on two distant branches of the tree,

61 implying that they may even represent distinct genera. I also recognized some small differences

62 between those two species, but after personal examination of material assigned to both species I

63 have to admit that differences in the postcranium of those two species are minor in general and

64 difficult to interpret, mostly due to small sample size and incompleteness of the preserved

65 elements in Scottish material and its likely younger ontogenetic age, as suggested by smaller 
66 sizes of the specimens and some other indicatives (e.g., lack of fusion between the elements of

67 the axial skeleton or pectoral girdle). Until some more comprehensive taxonomic and

68

ontogenetic study is performed and the definitive answer is found, I follow the division into two species proposed by Sulej (2010) and I assign the aetosaur forelimb elements described in this study to Stagonolepis olenkae.

In general, fossils of aetosaur forelimbs are less abundant than those of the hind limbs. In spite of that, the long bones of the forelimbs are recognized and well-described in several species (e.g., Sawin 1947; Walker 1961; Bonaparte 1971; Lucas et al. 2002; Schoch 2007; Heckert et al. 2010; Roberto-Da-Silva et al. 2014). Much less is known about aetosaurs' manus and carpus. In fact, those parts are described in detail only for Stagonolepis robertsoni, Longosuchus meadei, Typothorax coccinarum and recently Stagonolepis olenkae (Sawin 1947; Walker 1961; Lucas and Heckert 2011; Książkiewicz 2014; this study),but associated metacarpals with elements of carpus are known also for Aetosaurus ferratus (Schoch 2007). The material of Stagonolepis olenkae currently consists of a several isolated humeri, radii and ulnae, and few specimens with associated forearm, hand and carpal elements. Two of those specimens are illustrated by Książkiewicz (2014) in his doctoral thesis, and four are described and illustrated in this study.

\section{Based on the literature, large and middle size aetosaurs (over $2 \mathrm{~m}$ in length), like Longosuchus} meadei, Stagonolepis olenkae, Stagonolepis robertsoni, and Typothorax coccinarum, have forelimbs more similar to each other than to that the smaller aetosaurs (below $1 \mathrm{~m}$ in length), like Aetosaurus ferratus and Polesinesuchus aurelioi (Sawin 1947; Walker 1961; Long and Murry 1995; Schoch 2007; Heckert et al. 2010; Roberto-da-Silva 2014). However, in all species the forelimbs are shorter than the hind limbs, robust and strongly-built, with the humerus longer than 
88 the forearm bones, and the radius and ulna of comparable length (e.g., Sawin 1947; Walker

89 1961; Heckert et al. 2010; Desojo et al. 2013). The humerus has a wide, well-defined head and a

90 prominent deltopectoral crest (e.g., Heckert et al. 2010; Desojo et al. 2013). The ulna and radius

91 are straight and the olecranon process of the ulna is usually high (e.g., Desojo et al. 2013). In the

92 hand of known species, metacarpals and phalanges are short and wide, and the digits are finished

93 with claw-shaped unguals (e.g., Sawin 1947; Walker 1961; Lucas and Heckert, 2011; Desojo et

94 al. 2013). The probable phalangeal formula is 2-3-4-5-3 (Walker 1961; Desojo et al. 2013) with

95 the fifth digit much smaller than the others (Lucas and Heckert 2011). The carpus consists of few

96 (probably four) bony components (Sawin 1947; this study). The most characteristic carpal

97 element that distinguishes aetosaurs' carpus from that of other pseudosuchians is a large bone

98 adjacent to radius, probably the fused radiale and intermedium (Sawin 1947; Walker 1961;

99 Schoch 2007; Książkiewicz 2014, this study).

100 Probable use of the forelimbs for digging was already suggested for Stagonolepis robertsoni

101 by Walker (1961), based on the presence of short manus and an excavation below the proximal

102 end of the ulna. Adaptations for digging has been more comprehensively discussed by Heckert et

103 al. (2010) in respect to Typothorax coccinarum, known from almost complete and articulated

104 skeletons. T. coccinarum possesses five of eleven characters that, according to Hildebrand

105 (1988), indicate a digging behavior in modern vertebrates, namely: a low brachial index (radius

106 shorter than humerus), (1) a prominent deltopectoral crest that extends distally on the humerus,

107 (2) a wide entepicondyle, (3) short and wide metacarpals, (4) short and wide phalanges (Heckert

108 et al. 2010). In addition they pointed out that the compact and strongly articulated foot with a

109 large, curved and laterally compressed unguals could have been used for scratch-digging, as it

110 was suggested for the rhynchosaur Hyperodapedon (Heckert et al. 2010, Benton 1983). Based on 
111 the presence of such digging adaptations in T. coccinarum, it is suggested that it might have used

112 its limbs to unearth roots or burrowing invertebrates (Heckert et al. 2010; Desojo et al. 2013).

113 The digging features mentioned for T. coccinarum are also present in the forelimbs of

114 Stagonolepis olenkae, but the latter also has other characters that are indicative more specifically 115 for scratch-digging, according to Hildebrand (1983, 1988, Heckert et al. 2010).

116 The postcranial skeleton of Stagonolepis olenkae, including forelimbs, has been described by

117 Książkiewicz (2014) in his doctoral thesis. However, the research conducted for my paper was

118 done independently of his studies, and is based on different material (with exception of hand 119 elements of the specimen ZPAL AbIII/2071, which were only mentioned in his thesis but have 120 not been illustrated). I have personally examined the material used by Książkiewicz, but since he 121 wishes to publish his thesis soon, I will make only necessary references to his work, which have 122 an impact on the subject of my paper. My work contains more detailed description of the $S$.

123 olenkae forelimbs and discuss the probable scratch-digging behavior in this species, which is not 124 discussed by Książkiewicz (2014).

\section{Geological setting}

126 Krasiejów is located at the southern-eastern edge of the fore-Sudetic Homocline in Opole 127 Voivodeship (Upper Silesia), SW Poland. This was the first of the series of Late Triassic 128 localities in Silesia containing bones of large vertebrates discovered near the end of the 1990s, 129 supplemented later by the Lisowice, Poręba, Woźniki, and Marciszów localities in the beginning 130 of the 2000s (Dzik et al. 2000, 2008; Dzik 2001; Budziszewska-Karwowska et al. 2010; 131 Niedźwiedzki et al. 2012; Sulej et al. 2012; Szczygielski and Sulej 2016; Szczygielski 2017). 
132 The outcrop is located in an unoperational clay pit. The exact age of the beds exposed at

133 Krasiejów is not certain. Originally, a late Carnian age was proposed, based on biostratigraphic

134 evidence (Dzik et al. 2000; Dzik and Sulej 2007, 2016; Zatoń et al. 2005; Kozur and Weems

135 2010) but the lithostratigraphic correlations suggest the Norian age (Szulc et al. 2015).

136 Rocks deposited in Krasiejów consist mostly of red to red-brown or gray siltstones and

137 mudstones. Alternating series of red and gray rocks indicate a seasonal climate with dry (red)

138 and wet (gray) periods (Szulc 2005; Gruszka and Zieliński 2008). Lenses of fine-grained

139 sandstone and calcareous concretions (often containing bones) as well as several paleosol

140 horizons (Szulc 2005) occur in the section. Below the level of the outcrop the presence of

141 gypsum was reported (Szulc 2005).

142 The Krasiejów locality is one of the largest accumulations of fossil vertebrates in central

143 Europe. Specimens gathered from this locality number in the thousands. In addition to

144 Stagonolepis olenkae, the Krasiejów fauna includes the temnospondyls Metoposaurus

145 krasiejowensis and Cyclotosaurus intermedius, basal archosaurs, including a rauisuchian

146 Polonosuchus silesiacus and a phytosaur Paleorhinus (=Parasuchus) sp., the dinosauromorph

147 Silesaurus opolensis, the gliding protorosaurid Ozimek volans, fishes, and invertebrates (Dzik et

148 al. 2000; Dzik 2001, 2003a, 2003b, 2008; Sulej 2002, 2005, 2007, 2010; Sulej and Mayer 2005;

149 Dzik and Sulej 2007, 2016; Brussatte et al. 2009; Piechowski and Dzik 2010; Skrzycki 2015).

150 Plant remains are rare (Dzik et al. 2000; Dzik 2003b; Dzik and Sulej 2007; Pacyna 2014).

151 The majority of vertebrate fossils occur in two bone-bearing horizons (e.g., Dzik et al. 2000;

152 Dzik and Sulej 2007; Szulc 2007; Bodzioch and Kowal-Linka 2012). The lower bone horizon is 153 about $1 \mathrm{~m}$ thick, with a grey bed (about $0.3 \mathrm{~m}$ thick) at the bottom that is distinct from the red 
154 paleosol series below it, and the red bed in its upper part covered mostly by a layer of calcareous

155 grainstone and fluvial variegated sediments above. Most of the vertebrate fossils are preserved at

156 the boundary of the red and grey sediments within this bone horizon. Horizontal layering of

157 sediments indicates its deposition in open standing water (Dzik et al. 2000; Dzik and Sulej 2007;

158 Gruszka and Zieliński 2008). In this bone level, fossils of aquatic vertebrates dominate:

159 Metoposaurus krasiejowensis, Cyclotosaurus intermedius, and the phytosaur (Dzik et al. 2000;

160 Dzik 2003b; Dzik and Sulej 2007). Remains of terrestrial animals are less frequent, although

161 common (e.g., Stagonolepis olenkae, Silesaurus opolensis) (Dzik et al. 2000; Dzik 2003b; Dzik

162 and Sulej 2007). According to Bodzioch and Kowal-Linka (2012), the lower bone level was

163 deposited by a single short-lived, high energy event, probably a flood, which is contradicted by

164 strictly horizontal intercalations of grainstone.

165 The upper bone horizon (a few meters above the lower one) is a lenticular red mudstone body 166 within fluvial deposits. In contrast to the lower bone horizon, terrestrial vertebrates dominate 167 there, whereas aquatic ones are rare (Dzik 2003b, Dzik and Sulej 2007).

\section{Material and methods}

Four specimens with elements of forearms, carpus and hand preserved in association as well as several various isolated forelimb bones were examined. All humeri used in this study were found isolated. The studied material comes from both bone bearing horizons at the Krasiejów

172 locality. It is a part of the collection of the Institute of Paleobiology, Polish Academy of Sciences

173 in Warsaw. A complete list of specimens with the description, measurements, photographs and

174 taphonomical notes are provided in supplementary online materials (Appendix online 1-3, 175 supplementary Figures 1-9). 
176 Specimens were recognized as representing aetosaurs based on the general morphology of the

177 long bones and the relative proportions between the different elements, the presence of a well-

178 defined humeral head, with well-developed deltopectoral crest, the presence of a long olecranon

179 process in ulna, the presence of fused radiale and intermedium in the carpus, the massive and

180 thick digits, and the presence of osteoderms. Isolated bone elements were identified based on

181 comparison with specimens preserved in association, if possible. All were referred to

182 Stagonolepis olenkae, as there is only one species of aetosaur described thus far from Krasiejów.

183 The bones of Stagonolepis olenkae are more heavily built and stouter compared to those of

184 rauisuchian Polonosuchus silesiacus and phytosaur Paleorhinus (=Parasuchus) sp., with which

185 they may be confused. The humeri of aetosaurs in comparison to the humeri of phytosaurs have

186 more transversely expanded proximal head than in phytosaurs (the ratio between the entire

187 length of bone and width of the head in aetosaurs is around 0.53 (based on the humeri ZPAL

$188 \mathrm{AbIII} / 1175,2369,2627$ ) and in phytosaurs is around 0.35 (based on the humeri ZPAL

$189 \mathrm{AbIII} / 1994,502 / 38)$ ). In addition, the deltopectoral crest is more developed in aetosaurs and

190 significantly expanded laterally, while in phytosaurs the lateral margin of the shaft is straight

191 (Nesbitt 2011; Parker 2012; ZPAL AbIII/1994, 502/38). The ulnae of aetosaurs in comparison

192 with phytosaurs (e.g., ZPAL AbIII/3362) have more expanded proximal articulation surface with

193 pronounced coronoid process (Nesbitt 2011; Parker 2012).

194 All specimens were cleaned from the surrounding sediment mechanically (with a pneumatic

195 airscribe, PaleoTools model ME-9100) and chemically (with 5\% formic acid). Three

196 dimensional models of five specimens were obtained utilizing photogrammetry method with use

197 of several freeware programs (FastStone Photo Resizer, VisualSFM, MeshLab, Texture Stitcher, 
198 and DazStudio) and then implemented into .PDF files with Adobe Acrobat (Cignoni et al. 2008;

199 Chuang et al. 2009; Furakawa and Ponce 2010; Wu 2011; Khazdan and Hoppe 2013). Detailed

200 description of the process and 3D PDFs are provided in the supplementary materials (Appendix

201 online 4-9).

202 Results: Osteological description of the forelimbs of the aetosaur

203 Stagonolepis olenkae

204 Proportions and general description of the forelimb bones

205 Forelimb elements of Stagonolepis olenkae (humerus, Fig. 1; ulna and radius, Fig. 2-4; the

206 largest carpal bone - fused radiale and intermedium, fig. 5; manus, Fig. 6) are smaller than the

207 corresponding elements of the hind limbs, therefore the entire forelimb must have been shorter

208 than hind limb (personal observation; Książkiewicz 2014). The humerus is about two-thirds the

209 length of the femur (Książkiewicz 2014). The length ratio of the humerus ZPAL AbIII/2369 to

210 the femur ZPAL AbIII/691 is 0.69 (the specimens possibly belong to a single animal, because

211 they have been found close to each other in the same assemblage). Although there are no humeri

212 found in articulation with radius and ulna, it can be assumed that humerus in Stagonlepis olenkae

213 is longer than each of the forearm bones, based on the comparison of several specimens

214 (personal observation, Ksiażkiewicz 2014). Possibly the ulna ZPAL AbIII/1179 belongs to the 215 same animal as the humerus ZPAL AbIII/2369, because of their similar taphonomic condition 216 and relatively close position in the sediment at the moment of recovery. The length ratio of the

217 ulna ZPAL AbIII/1179 to the humerus ZPAL AbIII/2369 is 0.79. The radius and ulna are

218 orientated parallel to each other (Fig. 2; based on specimen ZPAL AbIII/2407). The ulna is

219 longer than the radius and more massive. The ratio of length between the radius and the ulna in 
220 the specimen ZPAL AbIII/2407 is 0.85 . The proximal ends of the radius and ulna form a single

221 articulation surface for the humerus. The joint between the radius and ulna is elongated and

222 crescent-shaped (Fig. 3A, 4B; based on ZPAL AbIII/3351, 3322), which seemingly makes the

223 relative rotation of these two bones impossible. The olecranon process of the ulna is high (Fig. 2,

224 3; based on ZPAL AbIII/2407, 2014, 3351), and in large specimens of humeri the olecranon

225 fossa is present (Fig. 1B; ZPAL AbIII/1175, 257). Based on specimen ZPAL AbIII/2407 the

226 manus together with the carpus is shorter than both the ulna and the radius (Fig. 2A-D). The

227 carpus consist of at least four bone elements. The largest one of them is probably a fused radiale

228 and intermedium (Fig. 5; ZPAL AbIII/2071, 2407, 3349/1, 3349/2). It is connected with the

229 radius and partially with the ulna at the forearm side and the metacarpals I-III and probably IV at

230 palm side. Its arrangement prevents rotation movements of the carpus and restricts moves of the

231 carpal joint only to a one sagittal plane. Metacarpals and phalanges (Fig. 6E) are stout, relatively

232 short and wide. Medial digits (II, III, IV) are almost of equal length and they are noticeably

233 longer than digits I and V, while digit I is longer than digit V (relative length of digits

$234 \mathrm{II} \sim \mathrm{III} \sim \mathrm{IV}>\mathrm{I}>\mathrm{V})$. Digit $\mathrm{I}$ is the most robust in the manus, the medial digits are of similar form and

235 massiveness, while digit $\mathrm{V}$ is the tiniest one in the hand. The phalangeal formula is probably 2-3-

236 4-5?-3? and at least digits I to III terminate with claw-like unguals (Fig. 6E, mostly based on

237 ZPAL AbIII/3349/1 and 2071). The ungual of the first digit is the largest one, and it is much

238 bigger than the rest. The ungual of the second digit is about one-third smaller than the first one,

239 and the sizes of following unguals decrease in the same pattern (Fig. 6E; based on ZPAL

$240 \mathrm{AbIII} / 3349 / 1,2071)$. The dorsal part of the hand, forearm and probably also upper arm is entirely

241 covered by osteoderms (Fig. 6F; based on ZPAL AbIII/2407, 3349/1, 3349/2). 
243 The humerus of Stagonolepis olenkae (Fig. 1), examined here in the specimen ZPAL

244 AbIII/257, 1175, 2627, is a massive, strongly built bone with a straight shaft and well-defined,

245 transversely wide, proximal and distal head. The shaft is twisted through about 30 degrees, so

246 that the distal end faces backward as well as upward. The proximal head expands into the

247 coronal plane, mostly medially, and is very wide, almost half of the length of the entire bone -

248 the ratio of the medio-lateral width of the humeral head to the entire length of the bone is about

2490.54 (Fig. 1A-B; ZPAL AbIII/1175, 2627). Its articulation surface is convex and it is covered by

250 multiple irregularly arranged tubercles of random size, which indicate the presence of a well-

251 developed cartilaginous cap (ZPAL AbIII/2627). The medial process of the proximal head forms

252 an internal tuberosity (it is almost as robust as the articular thickening). It is separated from the

253 main articulation surface by a pronounced indentation (ZPAL AbIII/1175, 2627). Below the

254 articulation surface of the proximal head the shaft gently slopes forming a short neck. Under the

255 medial process the neck forms a thin lamina. The deltopectoral crest is well-developed. It starts

256 below the level of the articulation surface of the humeral head and below the level of the internal

257 tuberosity (Fig. 1A-B; ZPAL AbIII/1175, 2627). The shaft in the medial/lateral view remains

258 straight throughout its entire length (Fig. 1C-D). In the dorsal/ventral view, the medial edge of

259 the humerus forms an arch (Fig. 1A-B). The arch is strongly bent, toward the lateral and distal

260 side, in the proximal portion of the shaft, then fluently transits into almost straight line in the

261 middle portion of the shaft, and bends again, toward the medial and distal side, above the medial

262 epicondyle. The shaft expands laterally, in the regions of the deltopectoral crest and the lateral

263 epicondyle, but the expansion is not as significant as on the medial side (Fig. 1A-B; ZPAL

$264 \mathrm{AbIII} / 1175,2627)$. The wide proximal portion of the shaft is much thinner than the middle and

265 distal section. Its thickness increases gradually from the neck of the proximal head, up to the end 
266 of the deltopectoral crest (Fig. 1D). On the dorsal surface of the shaft, next to the deltopectoral

267 crest, there is an elevation, which in the specimen ZPAL AbIII/2627 is ornamented by delicate

268 grooves. On the dorsal side, distal to the elevation, close to the medial edge, an elongated knob is

269 present (Fig. 1B). The ventral side of the shaft in the proximal section is smooth (Fig. 1A; ZPAL

$270 \mathrm{AbIII} / 1175,2627)$. The middle section of the shaft, below the deltopectoral crest up to the

271 epicondyles, is close to oval in cross-section and of uniform thickness and width. On the dorso-

272 lateral surface there is a straight furrow that originates in the elevated area next to deltopectoral

273 crest and continues up to the epicondyle (Fig. 1C; ZPAL AbIII/1175, 2627). The distal head of

274 the humerus is much narrower than the proximal head, being about 0.6 the length of the proximal

275 head and 0.25 the length of the entire bone. The entepicondyle is wide. The ectepicondylar

276 groove on the lateral side is fully exposed and deep (Fig. 1A-C; ZPAL AbIII/257, 1175, 2627).

277 The supinator process is thick and prominent (Fig. 1A-C; ZPAL AbIII/257). In large specimens

278 the olecranon fossa is present (Fig. 1B). In specimen ZPAL AbIII/257 the olecranon fossa is not

279 fully enclosed as in specimen ZPAL AbIII/1175. In distal view, the distal head is transversely

280 elongated, with pronounced narrowing in its center (Fig. 1F). The articulation surface of the

281 distal head is covered by multiple irregularly arranged tubercles of random size, which indicate

282 the presence of well-developed cartilaginous cap (ZPAL AbIII/257, 2627).

$283 U \ln a$

The ulna of Stagonolepis olenkae (Fig. 2, 3) represented by the specimen ZPAL AbIII/2407, $3349 / 1,3349 / 2,1100 / 1,1179,2014$, and 3351, is straight and dorso-ventrally flattened. The proximal portion of the shaft is triangular in cross-section and it is wider and thicker than the middle and distal portion. The olecranon process is long (around 0.2 of the total ulna length in 
288 the specimen ZPAL AbIII/2407 and 3351; Fig. 3A-D), but probably it was even longer as on its

289 top there is a tubercular area (Fig. 3B, D-E), which indicates the presence of well-developed

290 apical cartilage (ZPAL AbIII/2407, 2014, 3351). The tubercles are of different size and are

291 irregularly arranged. The articular surface for the humerus falls rapidly behind the tubercular

292 area of olecranon process towards the coronoid process, where it becomes almost flat (Fig. 3A-

293 B; ZPAL AbIII/2407, 2014, 3351). The coronoid process is elongated medially and prominent.

294 The articular surface for the radius (on the dorsal side, below the coronoid process) is elongated

295 and crescent-shaped (Fig. 3A; ZPAL AbIII/2014, 3351). The area below the olecranon process is

296 covered by an irregularly arranged and strongly marked series of pits and grooves (Fig. 2E, 3A-

297 B, D; ZPAL AbIII/2014, 2407, 3351). In crocodiles, this area is the insertion point for the triceps

298 muscle (Meers 2003). The presence of strongly marked structures in this region suggests that the

299 triceps muscle must have been well-developed in Stagonolepis olenkae. There is another small

300 ornamented area (with an ornamentation of small pits and grooves) on the dorsal side of the ulna,

301 in the proximal part of the shaft, distal to the articular surface for the radius (Fig. 2E, 3A; ZPAL

$302 \mathrm{AbIII} / 2014)$. Its ornamentation consists of small pits and grooves. The shaft in the middle section

303 forms two parallel, almost flat surfaces (on the dorsal and ventral side) and (in dorsal/ventral

304 view) slightly tapers symmetrically towards the distal end of the ulna, where a delicate neck can

305 be distinguished (Fig. 3 A-B; ZPAL AbIII/1100/1, 1179, 2014, 2407, 3351). The lateral edge of

306 the shaft in the middle section is smooth and rounded (Fig. 3D). The medial edge of the shaft, in

307 the middle section, ends with a furrow that initiates below the articular surface for the humerus

308 and the radius, continues throughout the middle portion of the shaft and weakens towards the

309 distal end of the ulna (Fig. 3C). The cross-section of the shaft, in the upper part of the middle

310 section, is similar to an irregular pentagon with two parallel sides (dorsal and ventral surfaces of 
311 ulna) and sharp edge oriented medially (where the furrow is). The shape of the cross-section

312 changes towards the distal end of the ulna and becomes more oval. On the dorsal side of the ulna,

313 in the middle section of the shaft, two other well marked longitudinal furrows can be recognized

314 (Fig. 2E, 3A). The first furrow on the dorsal surface, situated next to the lateral edge of the bone,

315 continues almost through the entire length of the shaft and is arched laterally in dorsal view. The

316 other one, situated next to the medial edge of the bone, is straight and continues only through the

317 middle section of the shaft. The ventral surface of the ulna forms a single flat plane with a small

318 longitudinal depression in the middle (Fig. 3B). The plane continues through the proximal and

319 the middle section of the shaft. In the distal part, distal to the delicate neck, the shaft slightly

320 expands and gently twists (Fig. 3C-D). In distal view, the shape of the surface for the wrist bones

321 is oval (Fig. 3F; ZPAL AbIII/2407, 3349/1). Similar to the proximal end, the distal end of the

322 ulna was also partially cartilaginous. Its bony surface is covered by irregularly distributed

323 tubercles, although much smaller than those in the region of the olecranon process (ZPAL

$324 \mathrm{AbIII} / 2407,3349 / 1,3351)$. Distal to the neck on the ventro-medial side, there is a prominent

325 oval ornamented area (Fig. 3A, C; ZPAL AbIII/3351). Its ornamentation consists of small,

326 irregularly arranged pits and grooves.

$327 \quad$ Radius

328 The radius (Fig. 4) represented by the specimen ZPAL AbIII/1628, 2407, 2016/2, 2016/4, $3293322,3349 / 1,3349 / 2$ is shorter than the ulna and longer than the manus. The ratio of length

330 between the radius and the ulna in the specimen ZPAL AbIII/2407 is 0.85 (Fig. 2A-D). The shaft

331 is straight and of almost uniform thickness throughout its entire length, except for the proximal

332 or distal ends, where it expands in a funnel-like manner (Fig. 4A-B). In dorsal-ventral view the 
333 proximal and distal ends are of the same width (Fig. 4A-B; ZPAL AbIII/3322). The articulation

334 surface for the humerus is orientated perpendicular to the shaft (Fig. 4A-B) and in proximal view

335 it is semi-rounded (Fig. 4E). Its surface is almost flat, with a tiny depression in the centre and a

336 small process at the lateral edge. The articulation surface for the ulna is crescent-shaped and

337 extends longitudinally (Fig. 4B, E; ZPAL AbIII/3322). The middle portion of the shaft is semi-

338 square in cross-section. Two corresponding, sharp, well-marked furrows are present on the

339 dorsal and the ventral side of the shaft (Fig. 4A-B; ZPAL AbIII/3322). Both furrows are s-

340 shaped, which gives the impression that the shaft is twisted helically. Two furrows of similar

341 pattern, but much less distinct, are also present on the lateral and the medial side of the shaft

342 (Fig. 4C-D). The bony surface of the articulation area with the carpus is semicircular in distal

343 view (Fig. 4F; ZPAL AbIII/2106/2, 2407, 3322). Its surface is covered by irregularly arranged

344 tubercles (ZPAL AbIII/2106/2), similar to those present on the olecranon process of the ulna and

345 the humeral heads, but smaller. The presence of the tubercles indicates a well-developed

346 cartilaginous finish.

347 Carpus

348 The carpus consists of at least four bony elements, probably oriented in two rows (Fig. 6E).

349 The largest carpal bone is the fused radiale and intermedium (Fig. 5), present in the spec. ZPAL

$350 \mathrm{AbIII} / 2407,3349 / 1,3349 / 2,2071$, which probably forms the proximal row with the narrow,

351 square-shaped ulnare, present in the specimen ZPAL AbIII/2407, 3349/1, 3349/2, and 2071. The

352 second row consist of at least two bony distal carpals (present in the specimen ZPAL AbIII/2071,

3532407 (only one), 3349/1, and 3349/2), among which one is larger and crescent-shaped and the

354 second one much smaller and pea-shaped. 
The fused radiale and intermedium (Fig. 5) is a thick bone, elongated in the coronal plane.

356 Proximally it articulates with the radius and partially the ulna, and is adjacent distally to

357 metacarpals I, II, III, and partially IV (Fig. 6; based on ZPAL AbIII/2407, 3349/1). Książkiewicz

358 (2014) described a single specimen (UOBS 02609), in which the radiale and the intermedium are

359 separated, but he suggested that the bone is probably broken. The radiale and intermedium are

360 joined together by a suture (Fig. 5M-N, R-S; ZPAL AbIII/2071, 3349/1). The suture is less

361 pronounced, or totally fades, in the ventral and middle portion of the bone, which suggests a

362 continuous process of fusion of both elements. It seems that the two bones initially ossified

363 separately and fused later in ontogeny. For the purpose of further description, the suture will be

364 used as reference point dividing the bone in two sections: the one corresponding to the radiale

365 and the second corresponding to the intermedium. In proximal-distal view the section

366 corresponding to the radiale is semi-oval or rounded and the section corresponding to the

367 intermedium is rectangular (Fig. 5M-N). In this views, the section corresponding to the radiale is

368 much larger than the section corresponding to intermedium. In dorsal-ventral view the shape of

369 the fused radiale and intermedium is close to rectangular (Fig. 5R-S). On the proximal side of the

370 bone, at the section corresponding to the radiale, the surface forms a prominent ridge

371 surrounding the center of the section dorsally and medially (Fig. 5M; ZPAL AbIII/2071).

372 Farther, on the proximal side at the section corresponding to the intermedium, a modest but

373 distinct elevation is present (Fig. 5M). The elevation originates at the middle of the proximal

374 articulation surface, and continues towards the dorsal edge of the bone forming a process-like

375 structure. On the distal side, at the section corresponding to the radiale, there is a large,

376 prominent tuber (Fig. 5N-O; ZPAL AbIII/2071). The tuber originates in the middle of the

377 articulation surface, and continues towards the distal edge, covering a little less than half of the 
378 section corresponding to the radiale (Fig. 5N). Excluding the tuber region, the articulation

379 surface of the distal side of the fused radiale and intermedium forms an almost uniform plane,

380 with a modest elevation close to the dorso-medial edge and in the section corresponding to the

381 intermedium (Fig 5N; ZPAL AbIII/2071). On the dorsal surface of the fused radiale and

382 intermedium, two distinct areas are visible, one at the section corresponding to the radiale, and

383 one at the section corresponding to intermedium (Fig. 5R, 6C; ZPAL AbIII/2071, 3349/1). The

384 area in the section corresponding to the radiale is flat with a small depression in its central part. It

385 continues through the medial and part of the ventral side of the section. The area in the section

386 corresponding to the intermedium forms a deep depression. Opposite to it, on the ventral side of

387 the section corresponding to the intermedium, there is another area that forms depression but it is

388 smaller and shallower (Fig. 5S; ZPAL AbIII/2071). The lateral side of the fused radiale and

389 intermedium forms one square-shaped articulation area with a prominent tuber in the distal-

390 dorsal corner (Fig. 5P).

391 The ulnare is a cube with square bases and rectangular sides. The width of the sides is half the

392 width of the bases. It was probably arranged in one line with the fused radiale and intermedium,

393 with the bases oriented proximally/distally (based on the specimen ZPAL AbIII/2407, 3349/1).

394 The bases are almost flat, with slight depressions in their centres.

395 The carpus consists of at least two other (probably distal) carpals. One of them (larger) is

396 elongated and lunar-shaped, and the other one is about five times smaller and pea-shaped. These

397 are probably distal carpals III and IV, and based on the specimens ZPAL AbIII/2407 and 3349/1

398 they are arranged adjacent to metacarpal III in the second (distal) row of carpals. 
The elongated lunar-shaped bone in specimen ZPAL AbIII/2071, alternatively may be

400

401

402

403

404

405

406

407

408

409

410

411

412

413

414

415

416

417

418

419

420 The shape of most gracile metacarpal V differs between specimens. In specimen ZPAL

interpreted as a pisiform, based on the comparison with modern scratch-digging mammals, such as badger (Hildebrand 1988). If true, it should be oriented in one line with ulnare. Presence of long pisiform is characteristic for digging mammals (Hildebrand 1988).

\section{Metacarpals}

The metacarpals (Fig. 6E) present in the specimen ZPAL AbIII/2071, 2102, 2407, 3349/1, 3349/2 and are robust, relatively short, wide and dorso-ventrally flattened. Their bases are wider than the heads. Their shafts taper towards the distal ends. They match and partially cover each other in dorsal view. Metacarpals II, III, and IV are of similar shape and length, and are noticeably longer than metacarpals I and V, which are about 0.75 their size (based on ZPAL AbIII/2071, 2407, 3349/1, 3349/2). Metacarpal I is slightly longer than metacarpal V. The relative length between the metacarpals I, II, and III vary among specimens. For example, in specimen ZPAL AbIII/3349/1, metacarpal IV is the longest, but in specimen ZPAL AbIII/2407 the longest is metacarpal III. Metacarpal I is the most robust, and metacarpal V the most gracile. The relationship of robustness can be described as $\mathrm{I}<\mathrm{II}<\mathrm{III}<\mathrm{IV}<\mathrm{V}$. The distal articulation surfaces of the metacarpals are slightly asymmetric, each with a larger tuber on the medial side. Metacarpal I is also the widest among the metacarpals (Fig. 6E; ZPAL AbIII/2071, 2407, 3349/1, 3349/2). Its shaft is flat dorsally and rectangular in cross-section. On the ventral surface it has a depression for the subsequent metacarpal. Metacarpals II, III, and IV are of similar shape (Fig. 6E; spec. ZPAL AbIII/2071, 2102, 3349/1, 3349/2). Their shafts are triangular in cross-section.

19 Like in metacarpal I, there is a depression on their dorsal surface for the subsequent metacarpal. 
$421 \mathrm{AbIII} / 3349 / 1$ and 3349/2 it is wide and flat. Its width is almost uniform throughout the entire

422 length, and the base and the head are not distinct. In the specimens ZPAL AbIII/2071 and 2407

423 the base and the head are much wider than the shaft and well-developed. The shaft is slender and

424 oval in cross-section.

\section{$425 \quad$ Phalanges}

The phalanges (Fig. 6E) are present in the specimen ZPAL AbIII/2407(Fig. 2A-D) - all

427 phalanges of the first row, ZPAL AbIII/3349/1 (Fig. 6A-D) - all phalanges of the first and 428 second digit, broken $1^{\text {st }}$ row phalanx of the third digit, the four phalanges of the fourth digit and $4291^{\text {st }}$ row phalanx of the fifth digit, ZPAL AbIII/3349/2 - all phalanges of the first row, ZPAL $430 \mathrm{AbIII} / 2071$ - in the right hand all phalanges of the first, second and third digit, in the left all 431 phalanges of the first and second digit, and ZPAL AbIII/257, 3352, 3353 - isolated phalanges.

432 The probable phalangeal formula for Stagonolepis olenkae is 2-3-4-5?-3? (Fig. 6E), based mostly 433 on the specimens ZPAL AbIII/3349/1 and 2071. The number of the phalanges for the first three 434 digits is certain, because they terminate with claw-like unguals preserved in the first two digits of 435 ZPAL AbIII/3349/1 (Fig. 6 A-D), and first three digits of the right manus and the first two of the left of the spec. ZPAL AbIII/2071. In ZPAL AbIII/3349/1 the phalanx of the $4^{\text {th }}$ row of the digit IV ends with an articulation surface, which indicates the presence of another phalanx or an ungual. However because of small size of the preserved $4^{\text {th }}$ phalanx, it is unlikely that there was more than one element following it (Fig. 6C-D). As for the fifth digit, the size of the $1^{\text {st }}$ row phalanx, compared to the size of other phalanges in ZPAL AbIII/3349/1, suggest that at least two

441 phalanges and an ungual were present. In UOBS 02834 described by Książkiewicz (2014), 442 containing hand elements preserved in articulation, two phalanges of the fifth digit are present. 
443 The phalanges are dorso-ventrally flattened, short, and wide (Fig. 6E). The phalanx base is

444 always wider than its head. The shaft narrows towards the distal end. It is rounded at the dorsal

445 side and flat at the ventral side. Both the base and the head are slightly asymmetric. In the heads

446 the tuber on the internal side is always larger than that on the external side and a depression is

447 present on the articulation surface. This feature is more pronounced in the phalanges closer to the

448 metacarpals. Interlocking phalangeal articular surfaces are wide and they extend deep into the

449 shaft. The grooves for ligament attachments are well marked in all phalanges despite their size

450 (Fig. 6E).

451 As mentioned above, claw-like unguals are present on at least the first three digits (Fig. 6E;

452 based on ZPAL AbIII/2071, 3349/1). The size of the claw-like unguals decreases in more lateral

453 digits. The largest claw-like ungual of the first digit is about one-third longer and more massive

454 than that of the second digit, and the second is longer and more massive than the third one in the

455 same manner (ZPAL AbIII/2071). It can be inferred from the size of the preserved phalanges that

456 other claw-like unguals (if present) kept this tendency. The unguals are laterally compressed,

457 with sharp edges at the top and bottom sides (similar to claws of, for example, armadillos,

458 pangolins, badgers) (Hildebrand 1988). They are tear-shaped in cross section but asymmetric,

459 with a depression on the medial surface (ZPAL AbIII/2071). Longitudinal grooves for ligaments

460 are well-marked on both lateral and medial surfaces. Almost the entire surface of the unguals is

461 covered by tiny and very densely distributed perforations (Fig. 6A-B, E; ZPAL AbIII/2071,

462 3349/1). Similar texture can be observed on the bony parts of horns, for example, in modern

463 bovids or in the unguals of armadillos (personal observation, Hildebrand 1983). It indicates the

464 presence of a well-developed keratin sheath. Considering the general morphology of the whole

465 hand it is probable that very small claw-like unguals were present on the fourth and the fifth 
466 digits. In some species of modern digging animals such as armadillos, pangolins, or moles often

467 one or several digits enlarge and take a blade-like shape useful for a scratch-digging, while the

468 others are considerably smaller, reduced or absent (Beddard 1992, Hildebrand 1988).

469 Dermal skeleton

470 Probably the entire forearm of Stagonolepis olenkae was covered by numerous appendicular

471 osteoderms (Fig. 6A-B, F). They are preserved in association with the arm, carpus and manus

472 elements in ZPAL AbIII/2071, 2407, 3349/1 and 3349/2. In the specimens ZPAL AbIII/2407,

$4733349 / 1$, and 3349/2 they are accumulated mostly on the dorsal side of the hand. In the spec.

474 ZPAL AbIII/2407 there is also a large cluster of osteoderms, previously recovered in front of the

475 distal end of radius and ulna, but removed during preparation (not illustrated). The appendicular

476 osteoderms are generally flat, plate-like structures, semi-round to semi-oval in dorsal/ventral

477 view. The edges of the osteoderms can be regular and smooth (mostly in the larger scutes) or

478 irregular and ridged (more often in smaller ones). They are of various sizes, the largest are about

$4792.5 \mathrm{~cm}$ in diameter (ZPAL AbIII/2407, separated cluster of osteoderms), the smallest around 0.5

$480 \mathrm{~cm}$ in diameter (several osteoderms in ZPAL AbIII/2407, 3349/1, and 3349/2). They are

481 ornamented on the dorsal surface. The ornamentation consists of delicate grooves and

482 depressions. The ventral surfaces of the appendicular osteoderms are smooth. On both dorsal and

483 ventral side of osteoderms, tiny openings for blood vessels are present.

484 The appendicular osteoderms in ZPAL AbIII/2407, 3349/1 and 3349/2 are significantly

485 displaced in regard to their in vivo position, likely because of transportation and early diagenesis

486 processes. However, some general observation can be made. The appendicular osteoderms cover

487 the entire dorsal surface of the carpus and the manus (Fig. 6F). The osteoderms that occur in this 
488 area are of various sizes and shapes, but generally they are semi-round and small to medium

489 (with diameter about 0.5 to $1.5 \mathrm{~cm}$ ). In more flexible regions, such as the carpus and joints of the

490 digits, the osteoderms are smaller, but in greater number than in more static regions, such as

491 above the metacarpal shafts, where they are larger but less numerous. As for the region of the

492 arm, it is likely that it was entirely covered by appendicular osteoderms in the manner restored

493 for Aetosaurs ferratus or Typothorax coccinarum (Schoch 2007, Heckert et al. 2010). The

494 osteoderms of the arm are larger (up to around $2.5 \mathrm{~cm}$ in diameter). The lack of articulation

495 structures on the surfaces of the appendicular osteoderms suggests that they did not overlap with

496 each other (unlike the rectangular osteoderms presents on the back of the animals), but rather lay

497 one next to another like the scutes of modern crocodiles and alligators (e.g., Grig and Gans

498 1993).

\section{Discussion}

500 Comparisons with other aetosaurs

501 The forelimbs of Stagonolepis olenkae are robust, with the humerus having a prominent wide 502 head and condyles, and well-developed deltopectoral crest, dorso-ventrally flattened ulna with

503 high olecranon process, straight stout radius, and sturdy short digits ending with claw-like

504 unguals, with flattened, wide metacarpals and phalanges. Based on the literature they are much

505 more similar to other large and middle size aetosaurs like Stagonolepis robertsoni, Longosuchus

506 meadei, Typothorax coccinarum, Typothorax antiquum, Desmatosuchus smalli, Desmatosuchus

507 spurensis, or Neoaetosauroides engaeus (Sawin 1947; Walker 1961; Bonaparte 1971; Small

508 1985; Long and Murry 1995; Heckert and Lucas 2002; Martz 2002; Parker 2008; Heckert et al.

509 2010; Desojo et al. 2013) and differ from the small ones like Polesinesuchus aureoli and 
510 Aetosaurus ferratus, in which the above features are less developed (Roberto-da-Silva et al.

511 2014, Schoch 2007). However Stagonolepis olenkae has also unique features in forelimbs that

512 distinguish it from other species in which they are known, namely (1) presence of dermal amour

513 covering the dorsal part of the manus, (2) presence of enlarged ungual of the first digit in regard

514 to other unguals of the manus, (3) and in having square cross-section of the radius. Detailed

515 comparisons of $S$. olenkae with other aetosaurs as well as notes on their variability are given in

516 the supplementary materials (Appendix online 10, supplementary figures 10-12).

517 Comment on Stagonolepis robertsoni and Stagonolepis olenkae.

518 I personally studied S. robertsoni material and I think that differences in the postcranial

519 skeleton between the $S$. olenkae and S. robertsoni are generally minor, which was first pointed 520 out by Lucas et al. (2007). Nevertheless I need to mention that material of S. robertsoni, which

521 consist mostly of casts and incomplete specimens, is often difficult to directly compare with $S$.

522 olenkae, as the specimens often do not have or not have enough preserved essential parts that

523 could be used in comparisons. On the other hand, Książkiewicz (2014) specified list of

524 differences in post-cranium between those two species, but does not include any forelimbs

525 characters. Referring to the description of $S$. robertsoni provided by Walker (1961), I have found

526 another three characters (in spite of those three unique for S. olenkae) that may distinguish those

527 two species, namely (1) the presence of an indentation on the humeral head that separates the

528 internal tuberosity and main articulation surface in S. olenkae, (2) a more transversely expanded

529 humeral head in S. olenkae (pointed out also by Parker 2016; 2018), (3) and a sharp ended

530 coronoid process in S. olenkae. It must be, nonetheless, remembered that Walker (1961) also 
531 based his interpretations on the same incomplete and poorly preserved material, and thus some of

532 his restorations may be speculative or inaccurate.

533 Probable scratch-digging behavior in Stagonolepis olenkae

534 Stagonolepis olenkae has several features present in modern scratch-diggers according to

535 Hildebrand $(1983,1985)$ and Coombs (1983) which are explained in detail in the supplementary

536 material (appendix online 11). Without a doubt, it was able to produce great out-forces with its

537 forelimbs. They are (1) of strong, robust build (2) with short radius (shorter than the humerus),

538 (3) have a short carpus, with short, stout metacarpals, and (4) have a short, broad phalanges. (5)

539 The deltopectoral crest of the humerus (attachment of deltoid muscles) is well-developed and (6)

540 spans almost half the length of the bone. In the distal part of the humerus, (7) the medial

541 entepicondyle is prominent and wide (comparable to that of armadillos, pangolins, anteaters, and

542 aardvarks; Hildebrand 1983), and on the lateral side (8) a distinct supinator process is present.

543 (9) The olecranon process of the ulna is long (minimum 0.2 of the total ulna length - the level of

544 scratch-digging ground squirrels (Hildebrand 1988), but for sure it was longer in S. olenkae,

545 because of cartilaginous expansion), and has strong and well-marked insertions of the triceps

546 muscle. Following the criteria used by Heckert et al. (2010) in regard to Typothorax coccinarum,

547 S. olenkae bears nine of the eleven characters associated with digging behavior.

548 Furthermore, the joints of Stagonolepis olenkae are modified for stabilizing the arm. The wrist

549 joint is hinge-like due to the presence of the fused radiale and intermedium. The radius and the

550 ulna are oriented parallel to each other and are immovable relative to each other in the elbow

551 joint. The head of the humerus is very expanded medio-laterally which suggest that it had higher

552 mobility in the horizontal than in the vertical plane. In the autopodium, the joints between the 
553 metacarpals and the phalanges are almost flat-ended, the joints between phalanges are slightly V-

554 shaped, and the surfaces of more proximal phalanges are not larger than those of the distal ones.

555 The second-to-last phalanges in the first, second, and third digits have enlarged distal ends with a

556 great curvature radius. The autopodial bones of $S$. olenkae did not have bony stops and I do not

557 recognize sesamoids, however the whole hand was covered by osteoderms that might stiffen it.

558 In modern crocodiles, dorsal osteoderms together with dorsal muscles form a complex structure

559 that strengthens the vertebral column (Frey 1988). The small number of free phalanges (one in

560 the first digit and two in the second digit), obviously helped in the digging process, however, it is

561 a typical condition in crocodiles and among many basal archosaurs (for example Postosuchus,

562 Parasuchus, Riojasuchus) (Bonaparte 1971; Szarski 1976; Chatterjee 1978; Peyer et al. 2008;

563 Weinbaum 2013).

564 The manus of Stagonolepis olenkae was also adapted for breaking compacted soil. Its unguals

565 are laterally compressed, claw-like, and elongated in the manner of modern armadillos,

566 pangolins, echidnas, or moles (Hildebrand 1983). Their surface ornamentation is similar to that

567 on the unguals of, for example, armadillos (Hildebrand 1983), or on the bony surface of Bovidae

568 horns (personal observation), which indicates the presence of a strong keratin sheath. In addition,

569 the ungual of the first digit in S. olenkae is enlarged in respect to the others, similar to what is

570 found in some pangolins and armadillos in which the primary digging digit become enlarged

571 (Beddard 1902; Hildebrand 1983, 1988; Gaudin et al. 2016).

$572 \quad$ Implications for mode of life in Stagonolepis olenkae

573 Sulej (2010), based on the presence of a skull endocast with a very large olfactory tract and

574 bulbous, large nares, and the shape of teeth, considered Stagonolepis olenkae to be an 
575 omnivorous animal relaying mostly on smell in its search for food and using its shovel-like snout

576 to extract invertebrates and plants from under the ground, and comparing its lifestyle to modern

577 wild boars. Considering several adaptations for scratch-digging recognized here for S. olenkae, it

578 safe to assume that it probably started digging with its forelimbs to break and loosen the soil, and

579 then proceeded with its snout. Modern scratch-diggers (such as armadillos, pangolins, and

580 aardvarks) can balance their body with hind limbs and long tail to apply additional strength for a

581 breaking strike (Hildebrand 1988), which is also expected in S. olenkae, due to its relatively large

582 size and long tail (a feature characteristic of aetosaurs, Desojo et al. 2013, described also for $S$.

583 olenkae by Książkiewicz 2014).

584 The presence of specialized claws, together with the dermal armor covering the entire

585 forelimb suggests an analogy to the insectivorous mode of life of armadillos or pangolins,

586 considered by some authors to be modern analogues of aetosaurs (e.g., Bonaparte 1978; Small

587 2002; Desojo et al. 2013). The armor protects them against the insects (ants, termites or beetles)

588 they mostly feed on, as well as larger predators they cannot outrun (for example leopards or

589 hyena in the case of pangolins) (e.g., Talmage and Buchanan 1954; Deligne et al. 1981; Yang et

590 al. 2013; Wang et al. 2016). A few beetle elytra have been reported from Krasiejów (Dzik and

591 Sulej 2007) and the diet of the nine-banded armadillo may consist of even $40 \%$ of coleopterans

592 (Talmage and Buchanan 1954). Several authors suggest therefore the beetles could be the

593 important source of food for aetosaurs (e.g., Small 2002); however, it is hard to imagine an

594 animal being almost as long as a mid-sized automobile to base its diet mostly on insects.

595 Accordingly, the wild boar analogy seems more appropriate because of $S$. olenkae's overall size.

596 Besides, the wild boar's omnivorous diet includes roots, tubers, bulbs, nuts, seeds, bark, insects,

597 and other smaller animals, and also includes scavenging, but the majority of its food consists of 
598 items dug from the ground (Heptner et al. 1988). This covers every kind of feeding behavior that 599 has ever been suggested for aetosaurs (Desojo et al. 2013). Enlarged osteoderms forming an 600 extensive dermal carapace are most likely a result of a selective pressure from large predators, 601 rather than protection against small arthropods. The upper size range of aetosaurs is comparable 602 to associated rauisuchids, which possibly hunted them (Drymala and Bader 2012) and in 603 Krasiejów, S. olenkae is the only large land animal of a size comparable to the local predator 604 Polonosuchus silesiacus (e.g., Dzik and Sulej 2007). Still, S. olenkae is the only known aetosaur 605 with the osteoderms covering the dorsal surface of the hand. As the osteoderms take part in 606 thermoregulation (Farlow et al. 2010) and may buffer lactic acid (Jackson et al. 2003), their 607 presence may support S. olenkae's warming up or giving up heat generated by the intense work 608 of the forelimb muscles, and help to sustain longer high activity of the forelimbs.

609 During the deposition of bone-bearing horizons in Krasiejów, the climate was semi-tropical 610 with distinct seasonal wet and dry periods (Gruszka and Zieliński 2008). In modern tropical 611 areas during the dry season deciduous plants (including trees, shrubs, herbaceous) protect 612 themselves against dehydration by losing their foliage, and some of them develop resting 613 underground organs rich in storage polysaccharides and proteins (Bullock and Solis-Magallanes 614 1990). Stagonolepis olenkae may have temporarily relied on such source of food. A similar 615 climate with distinct seasonal wet and dry periods was also recognized in Upper Triassic Chinle 616 Formation in the USA (e.g., Dubiel 1984, 1987; Simms and Ruffell 1990), from which several 617 aetosaur species have been described (e.g., Desmatosuchus, Typothorax, Paratypothorax, 618 Calyptosuchus, Scutarx; Long and Ballew 1985; Long and Murry 1985; Heckert and Lucas 619 2000; Desojo et al. 2013; Parker 2016, 2018). 

mid-sized and large aetosaurs. Namely (1) robust forelimb bones, with (2) the humerus having a prominent, well-developed deltopectoral crest, and (3) a wide entepicondyle (Aetobarbakinoides brasiliensis, Argentinosuchus bonapartei, Desmatosuchus smalli, Desmatosuchus spurensis, Longosuchus meadei, Neoaetosauroides engaeus, Typothorax coccinarum, Typothorax antiquum, Stagonolepis robertsoni), (4) marked supinator process (S. robertsoni), (5) long and marked olecranon process of ulna (D. smalli, L. meadei, N. engaeus, T. coccinarum, T. antiquus, S. robertsoni), (6) short and stout metacarpals, (7) short and broad phalanges (L. meadei, T. coccinarum, S. robertsoni), and (8) the fused radiale and intermedium in the carpus (L. meadei and S. robertsoni) (Sawin 1947; Walker 1961; Small 1985; Long and Murry 1995; Lucas et al. 2002; Heckert and Lucas 2002; Martz 2002; Lucas and Heckert 2011; Desojo et al. 2012). Many 634 of mid-sized and large aetosaurs also have the shovel-like expansion at the end of the snout (e.g., 635 D. smalli, D. spurensis, L. meadei, N. engaeus, T. coccinarum, S. robertsoni) (Sawin 1947;

636 Walker 1961; Small 2002; Parker 2005, 2008; Desojo and Baéz 2007; Heckert et al. 2010;

637 Desojo et al. 2013). Therefore, it is probable that many of them could also perform scratch638 digging, and had a similar mode of life as Stagonolepis olenkae.

639 Despite the lack of many characters typical for diggers, the forelimbs of diminutive 640 Aetosaurus ferratus have proportions typical for digging animals, with the radius shorter than the 641 humerus, and the palm shorter than the radius (Schoch 2007). Aetosaurus ferratus also has a 
642 prominent supinator process and transversely elongated element in the carpus (radiale), but lacks

643 the shovel expansion in the snout (Schoch 2007). This suggests that it could also perform

644 scratch-digging with the forelimbs (probably even better than contemporary animals), but not to

645 the degree of larger aetosaur species.

\section{Conclusions}

647 The forelimbs of Stagonolepis olenkae have a morphology characteristic for large and middle

648 sized aetosaurs (over $2 \mathrm{~m}$ long, such as Desmatosuchus, Typothorax, Longosuchus) and differs

649 greatly from the smaller ones (below $1 \mathrm{~m}$ long, such as Aetosaurus, Polisinesuchus).

650 Stagonolepis olenkae, also has few features that have not been described thus far for any other

651 aetosaur, namely (1) presence of dermal armor covering the dorsal part of the manus, (2) the

652 presence of an enlarged ungual of the first digit, (3) and having a square cross section of the

653 radius.

654 It appears that some of the features observed in the forelimbs of all aetosaurs, like the

655 transverse expansion of the humeral head, transverse expansion of the condyles, elongation of

656 the olecranon process of the ulna and general increase of bone robustness, are associated with the

657 increase of size of certain species. However, to fully understand complexity of this process

658 among aetosaurs, further studies on ontogeny and intraspecific variation are needed.

659 Six characters that distinguish Stagonolepis olenkae and Stagonolepis robertsoni have been

660 recognized in this study (in addition to three unique for S. olenkae) (4) more transversely

661 expanded humeral head in $S$. olenkae, (5) distinct greater trochanter (internal tuberosity) in $S$.

662 olenkae, and (6) sharp ended coronoid process of ulna in S. olenkae). Additionally some 
663 specimens of S. olenkae have an olecranon fossa not present in S. robertsoni. These differences

664 may furthermore support the distinction of those two species, therefore supporting the

665 establishment of the species S. olenkae for the Polish material. However, this statement needs to

666 be treated with caution, because the intraspecific variation and particularly the ontogeny of both

667 species is not well known yet, and the described material of S. robertsoni usually does not allow

668 for the detailed comparisons due to the poor state of preservation.

Stagonolepis olenkae was an effective scratch-digger. It has many adaptations associated with

670 producing great forces against hard substrates, stabilizing the joints, and breaking compacted

671 soils. It probably started digging with its forelimbs to loosen and shatter the earth, and then

672 proceeded with its shovel-expansion at the tip of the snout, in search for food underground.

673 Characters connected with scratch-digging can be recognized also in forelimbs of other

674 aetosaur species, and in most of them they are associated with the presence of the shovel-like

675 expansion in the skull. Therefore the scratch-digging behavior proposed here for $S$. olenkae was

676 probably widespread among mid- and large-sized aetosaurs.

677 Possible digging behavior in aetosaurs could have co-evolved in an environment with

678 seasonal dry and wet periods like that present during the deposition of the Krasiejów strata. In

679 such environments, many plants develop underground resting organs of high dietary value,

680 which could serve as a source of energy during drought.

681 Acknowledgements. I would like to thank my supervisors Tomasz Sulej and Jerzy Dzik, for

682 guidance and help during the research and work on this paper; Tomasz Szczygielski for checking

683 the early version of the text and figures, and advices on how to improve it; Mateusz Tałanda, 
684 Grzegorz Niedźwiedzki, Julia Desojo, and Martin Ezcurra for advice on manuscript and sharing 685 literature with me; Voltaire Neto for sharing with me some photos and information about South 686 American aetosaurs; Michel Kazhdan for helping me with the Texture Stitcher; Stig Walsh, Janet 687 Trythall and all volunteers of Elgin Museum, especially Alison Wright and Dave Longstaff for 688 being great hosts during my visit in Scotland; Krzysztof Książkiewicz, for sharing his doctoral 689 thesis with me and showing me the collection it was based on; Justyna Słowiak, Przemysław 690 Świś, Łukasz Czepiński, and Maciej Pindakiewicz for discussion and technical comments about 691 the research and the paper; William Parker and the second anonymous reviewer for corrections 692 and advice on improvement of the manuscript; and my beloved Emilia Sałatkiewicz for advice 693 on improvement of the figures and emotional support.

\section{References}

ANTCZAK, M. 2015. Late Triassic aetosaur (Archosauria) from Krasiejów (SW Poland): new species or an example of individual variation? Geological Journal, 51, 779-788.

BEDDARD, F. E. 1902. Mammalia. Macmillan and Company, London, 638 pp.

BENTON, M. J. 1983. The Triassic reptile Hyperodapedon from Elgin: functional morphology and relationships. Philosophical Transactions of the Royal Society of London, Series B, 302, 605-718.

BODZIOCH, A. and KOWAL-LINKA, M. 2012. Unraveling the origin of the Late Triassic multitaxic bone accumulation at Krasiejów (S Poland) by diagenetic analysis. Palaeogeography, Palaeoclimatology, Palaeoecology, 346, 25-36. 
704 705

BONAPARTE, J. F. 1971. Los tetrapodos del sector superior de la Formacion los Colorados, La Rioja, Argentina (Triasico Superior). Part I. Opera Lilloana, 22, 1-188.

BONNAN, M. F., WILHITE, D. R., MASTERS, S. L., YATES, A. M., GARDNER, C. K., and AGUIAR, A. 2013. What lies beneath: sub-articular long bone shape scaling in eutherian mammals and saurischian dinosaurs suggests different locomotor adaptations for gigantism. PloS One, 8, e75216, https://doi.org/10.1371/journal.pone.0075216.

BRUSATTE, S. L., BENTON, M. J., DESOJO, J. B., and LANGER, M. C. 2010. The higherlevel phylogeny of Archosauria (Tetrapoda: Diapsida). Journal of Systematic Palaeontology, 8, 3-47.

— BUTLER, R. J., SULEJ, T. and NIEDŹWIEDZKI, G. 2009. The taxonomy and anatomy of rauisuchian archosaurs from the Late Triassic of Germany and Poland. Acta Palaeontologica Polonica, 54, 221-230.

BUDZISZEWSKA-KARWOWSKA, E., BUJOK, A., and SADLOK, G. 2010. Bite marks on an Upper Triassic dicynodontid tibia from Zawiercie, Kraków-Częstochowa Upland, southern Poland. Palaios, 25, 415-421.

BULLOCK, S. H. and SOLIS-MAGALLANES, J. A. 1990. Phenology of canopy trees of a tropical deciduous forest in Mexico. Biotropica, 22, 22-35.

BURNS, M. E., VICKARYOUS, M. K., and CURRIE, P. J. 2013. Histological variability in fossil and recent alligatoroid osteoderms: systematic and functional implications. Journal of Morphology, 274, 676-686. 
724 BUSCALIONI, A. D., ORTEGA, F., RASSKIN-GUTMAN, D. and PÉREZ-MORENO, B. P. 725 1997. Loss of carpal elements in crocodilian limb evolution: morphogenetic model

726

727

728

729

730

731

732

733

734

735

736

737

738

739

740

741

742 corroborated by palaeobiological data. Biological Journal of the Linnean Society, 62, 133144.

CASAMIQUELA, R. M. 1960. Notica preliminar sobre dosnuevos estagonolepoideos Argentinos. Ameghiniana, 2, 3-9.

CIGNONI, P., CALliERI, M., CORSINI, M., DELlEPIANE, M., GANOVELLI, F. and RANZUGLIA, G. 2008. Meshlab: an open-source mesh processing tool. Sixth Eurographics Italian Chapter Conference, pp. 129-136.

CHATTERJEE, S. 1978. A primitive parasuchid (phytosaur) reptile from the Upper Triassic Maleri Formation of India. Palaeontology, 21, 83-127.

CHUANG, M., LUO, L., BROWN, B. J., RUSINKIEWICZ, S. and KAZHDAN, M. 2009. Estimating the Laplace Beltrami Operator by Restricting 3D Functions. Computer graphics forum, 28, 1475-1484.

COOMBS, M. C. 1983. Large mammalian clawed herbivores: a comparative study. Transactions of the American Philosophical Society, 73, 1-96.

DELIGNE, J., QUENNEDEY, A. and BLUM, M. S. 1981. The enemies and defense mechanisms of termites. In HERMAN, H. R. (ed.) Social insects. Volume II. Academic Press, New York, London, Toronto, Sidney, San Francisco, pp. 1-76. 
743 DESOJO, J. B. and BÁEZ, A. M. 2005. El esqueleto postcraneano de Neoaetosauroides

744 (Archosauria: Aetosauria) del Triásico Superior del centro-oeste de Argentina.

$745 \quad$ Ameghiniana, 42, 115-126.

746 - 2007. Cranial morphology of the Late Triassic South American archosaur

747 Neoaetosauroides engaeus: evidence for aetosaurian diversity. Palaeontology, 50, 267-

$748 \quad 276$.

— and EZCURRA, M. D. 2011. A reappraisal of the taxonomic status of Aetosauroides

750 (Archosauria, Aetosauria) specimens from the Late Triassic of South America and their

751 proposed synonymy with Stagonolepis. Journal of Vertebrate Paleontology, 31, 596-609.

752 - and VIZCAÍNO, S. F. 2009. Jaw biomechanics in the South American aetosaur

753 Neoaetosauroides engaeus. Paläontologische Zeitschrift, 83: 499-510.

754 - EZCURRA, M. D. and KISCHLAT, E. E. 2012. A new aetosaur genus (Archosauria:

755 Pseudosuchia) from the early Late Triassic of southern Brazil. Zootaxa, 3166, 1-33.

756 - HECKERT, A. B., MARTZ, J. W., PARKER, W. G., SCHOCH, R. R., SMALL, B. J. and

757 SULEJ, T. 2013. Aetosauria: a clade of armoured pseudosuchians from the Upper Triassic

758 continental beds. In NESBITT, S. J., DESOJO, J. B. and IRMIS, R. B. (eds) 2013.

759 Anatomy, Phylogeny and Palaeobiology of Early Archosaurs and their Kin. Geological

760 Society, London, Special Publications, 379, 203-239.

DRYMALA, S. M. and K. BADER. 2012. Assessing predator-prey interactions through the 762 identification of bite marks on an aetosaur (Ppseudosuchia) osteoderm from the Upper 
763 Triassic (Norian) Chinle Formation in Petrified Forest National Park (Arizona, USA).

$764 \quad$ Journal of Vertebrate Paleontology, Program and Abstracts, p. 89.

765 DUBIEL, R. F. 1984. Evidence for wet paleoenvironments, Upper Triassic Chinle Formation, 766 Utah. Geological Society of Ameria, Abstracts with Programs, 16, p. 220.

767 - 1987. Sedimentology of the Upper Triassic Chinle Formation, southeastern Utah:

768 paleoclimatic implications. In Morales, M. and Elliott, D. (eds) Triassic continental

769 deposits of the American Southwets. Journal of the Arizona-Nevada Academy of Science,

$770 \quad 22,35-45$.

771 DZIK, J. 2001. A new Paleorhinus fauna in the early Late Triassic of Poland. Journal of 772 Vertebrate Paleontology, 21, 625-627.

$773-2003 a$. A beaked herbivorous archosaur with dinosaur affinities from the early Late Triassic 774 of Poland. Journal of Vertebrate Paleontology, 23, 556-574.

775 - 2003b. Krasiejów - u zarania ery dinozaurów. Ewolucja, 1, 2-13.

776 - 2008. Gill structure and relationships of the Triassic cycloid crustaceans. Journal of $777 \quad$ Morphology, 269, 1501-1519.

778 - and SULEJ, T. 2007. A review of the early Late Triassic Krasiejów biota from Silesia, 779 Poland. Paleontologia Polonica, 64, 3-27.

780 - 2016. An early Late Triassic long-necked reptile with a bony pectoral shield and gracile 781 appendages. Acta Palaeontologica Polonica, 61, 805-823. 
782 - NIEDŹWIEDZKI, G. and SULEJ, T. 2008. Zaskakujące uwieńczenie ery gadów

783 ssakokształtnych. Ewolucja, 3, 2-21.

784 - SULEJ, T., KAIM, A. and NIEDŹWIEDZKI, R. 2000. Późnotriasowe cmentarzysko

785 kręgowców lądowych w Krasiejowie na Śląsku Opolskim. Przegląd Geologiczny, 48, 226-

$786 \quad 235$.

787 FARLOW, J. O., HAYASHI, S. and TATTERSALL, G. J. 2010. Internal vascularity of the 788 dermal plates of Stegosaurus (Ornithischia, Thyreophora). Swiss Journal of Geosciences, $789 \quad \mathbf{1 0 3}, 173-185$.

790

791

792

793

794

795

796

797

798

799

800

801

FURUKAWA, Y. and PONCE, J. 2010. Accurate, dense, and robust multiview stereopsis. IEEE transactions on pattern analysis and machine intelligence, 32, 1362-1376. http://dx.doi.org/10.1109/TPAMI.2009.161.

GAUDIN, T. J., EMRY, R. J. and MORRIS, J. 2016. Skeletal Anatomy of the North American Pangolin Patriomanis Americana (Mammalia, Pholidota) from the Latest Eocene of Wyoming (USA). Smithsonian Institution Scholarly Press, Washington DC, 102 pp.

GRIGG, G. and GANS, C. 1993. Morphology and physiology of the Crocodylia. In GLASBY C. G., ROSS G. J. B. and BEESLEY P. L. (eds.). 1993. Fauna of Australia - Volume 2A, Amphibia and Reptilia. AGPS Canberra, pp. 326-336.

GRUSZKA, B. and ZIELIŃSKI, T. 2008. Evidence for a very low-energy fluvial system: a case study from the dinosaur-bearing Upper Triassic rocks of Southern Poland. Geological Quarterly, 52, 239-252. 
802 HECKERT, A. B. and LUCAS, S. G. 2000. Taxonomy, phylogeny, biostratigraphy, 803 biochronology, paleobiogeography, and evolution of the Late Triassic Aetosauria 804 (Archosauria: Crurotarsi). Zentralblatt für Geologie und Paläontologie, Teil I, 1998, 1539$805 \quad 1587$.

806 807 808 809
— - 2002. South American occurrences of the Adamanian (Late Triassic: latest Carnian) index taxon Stagonolepis (Archosauria: Aetosauria) and their biochronological significance. Journal of Paleontology, 76, 852-863.

- - RINEHART, L. F., CELESKEY, M. D., SPIELMANN, J. A. and HUNT, A. P. 2010. Articulated skeletons of the aetosaur Typothorax coccinarum Cope (Archosauria:

Stagonolepididae) from the Upper Triassic Bull Canyon Formation (Revueltian: early-mid Norian), eastern New Mexico, USA. Journal of Vertebrate Paleontology, 30, 619-642.

HEPTNER, V. G., NASIMOVICH, A. A., BANNIKOV, A. G. and HOFFMAN, R. S. 1989. Mammals of the Soviet Union, Volume 1, Artiodactyla and Perissodactyla. Smithsonian Institution Libraries and The National Science Foundation, Washington DC, 1147pp.

HILDEBRAND, M. 1983. Digging of quadrupeds. In HILDEBRAND, M., BRAMBLE, D. M., LIEM, K. F. and WAKE, D. B. (eds.), Functional Vertebrate Morphology. Harvard University Press, Cambridge, Massachusetts, pp. 89-109.

— 1988. Analysis of Vertebrate Structure. Third Edition. John Wiley and Sons, New York, 701 pp. 
821 HUENE, F. VON. 1939. Die Lebensweise der Rhynchosauriden. Paläontologische Zeitschrift $822 \quad 21,232-238$.

823 JACKSON, D. C., ANDRADE, D. V. and ABE, A. S. 2003. Lactate sequestration by osteoderms 824 of the broad-nose caiman, Caiman latirostris, following capture and forced submergence. 825 Journal of Experimental Biology, 206, 3601-3606.

826 KAZHDAN, M. and HOPPE, H. 2013. Screened poisson surface reconstruction. ACM 827 Transactions on Graphics (TOG), 32, 29.

828

829

830

831

832

833

834

835

836

837

838

KOZUR, H. W. and WEEMS, R. E. 2010. The biostratigraphic importance of conchostracans in the continental Triassic of the northern hemisphere. Geological Society, London, Special Publications, 334, 315-417.

KSIĄŻKIEWICZ, K. 2014. Morfo-funkcjonalna analiza szkieletu postkranialnego opancerzonego archozaura rodzaju Stagonolepis z późnego triasu polski. Unpublished Doctoral's thesis. Uniwersity of Wrocław, Wrocław, $147 \mathrm{pp}$.

LONG, R. A. and MURRY, P. A. 1995. Late Triassic (Carnian and Norian) Tetrapods from the Southwestern United States: Bulletin 4 (Vol. 4), Chapter 6, New Mexico Museum of Natural History and Science, Albuquerque, pp. 66-116.

LUCAS, S. G. and HECKERT, A. B. 2011. Late Triassic aetosaurs as the trackmaker of the tetrapod footprint ichnotaxon Brachychirotherium. Ichnos, 18, 197-208. 
839 - - and HUNT, A. P. 2002. A new species of the aetosaur Typothorax (Archosauria:

840 Stagonolepididae) from the Upper Triassic of east-central New Mexico. New Mexico

841 Museum of Natural History and Science Bulletin, 21: 221-233.

842 - SPIELMANN, J. A. and HUNT, A. P. 2007. Biochronological significance of Late Triassic

843 tetrapods from Krasiejów, Poland. The Global Triassic. New Mexico Museum of Natural

$844 \quad$ History and Science Bulletin, 41, 248-258.

845 LYDDEKER, R. 1885. The Reptilia and Amphibia of the Maleri and Denwa Groups.

846 Palaeontologia Indica, Series 4, 1, 1-38.

847 MARTZ, J. W. 2002. The morphology and ontogeny of Typothorax coccinarum (Aarchosauria, 848 Stagonolepididae) from the upper triassic of the american southwest. Unpublished master's 849 thesis. Texas Tech University, Lubbock, Texas, 279 pp.

850

851

852

853

854

855

856

857

858

MEERS, M. B. 2003. Crocodylian forelimb musculature and its relevance to Archosauria. The Anatomical Record Part A: Discoveries in Molecular, Cellular, and Evolutionary Biology, 274, 891-916.

NESBITT, S. J. 2011. The early evolution of archosaurs: relationships and the origin of major clades. Bulletin of the American Museum of Natural History, 352, 1-292.

NIEDŹWIEDZKI, G., SULEJ, T. and DZIK, J. 2012. A large predatory archosaur from the Late Triassic of Poland. Acta Palaeontologica Polonica, 57, 267-276.

PACYNA, G. 2014. Plant remains from the Polish Triassic. Present knowledge and future prospects. Acta Palaeobotanica, 54: 3-33. 
859 PADIAN, K., LI, C. and PCHELNIKOVA, J. 2010. The trackmaker of Apatopus (Late Triassic,

860 North America): implications for the evolution of archosaur stance and gait.

861 Palaeontology, 53, 175-189.

862 PARKER, W. G. 2005. A new species of the Late Triassic aetosaur Desmatosuchus

863 (Archosauria: Pseudosuchia). Comptes Rendus Palevol, 4, 327-340.

$864-2008$. Description of new material of the aetosaur Desmatosuchus spurensis (Archosauria:

865 Suchia) from the Chinle Formation of Arizona and a revision of the genus Desmatosuchus.

866 PaleoBios, 28, 1-40.

867 - 2012. Redescription and taxonomic status of specimens of Episcoposaurus and Typothorax,

868 the earliest known aetosaurs (Archosauria: Suchia) from the Upper Triassic of western

869 North America, and the problem of proxy "holotypes". Earth and Environmental Science

870 Transactions of the Royal Society of Edinburgh, 103, 313-338.

871 - 2016. Revised phylogenetic analysis of the Aetosauria (Archosauria: Pseudosuchia); assessing

872 the effects of incongruent morphological character sets. PeerJ, 4, e1583. DOI

$873 \quad 10.7717$ peerj.1583.

874 - 2018. Redescription of Calyptosuchus (Stagonolepis) wellesi (Archosauria: Pseudosuchia:

875 Aetosauria) from the Late Triassic of the Southwestern United States with a discussion of

876 genera in vertebrate paleontology. PeerJ, 6, e4291. DOI: 10.7717/peerj.4291.

877 PARRISH, J. M. 1986. Locomotor adaptations in the hindlimb and pelvis of the Thecodontia.

$878 \quad$ Hunteria, 1, 3-35. 
879 PEYER, K., CARTER, J. G., SUES, H. D., NOVAK, S. E. and OLSEN, P. E. 2008. A new 880 suchian archosaur from the Upper Triassic of North Carolina. Journal of Vertebrate $881 \quad$ Paleontology, 28, 363-381.

882 883 884 885 886 887 888

PIECHOWSKI, R. and DZIK, J. 2010. The axial skeleton of Silesaurus opolensis. Journal of Vertebrate Paleontology, 30, 1127-1141.

ROBERTO-DA-SILVA, L., DESOJO, J. B., CABREIRA, S. F., AIRES, A. S., MUELLER, R. T., PACHECO, C. P. and DIAS-DA-SILVA, S. 2014. A new aetosaur from the Upper Triassic of the Santa Maria Formation, southern Brazil. Zootaxa, 3764, 240-278.

SAWIN, H. J. 1947. The pseudosuchian reptile Typothorax meadei. Journal of Paleontology, 21, 201-238.

SCHOCH, R. R. 2007. Osteology of the small archosaur Aetosaurus from the Upper Triassic of Germany. Neues Jahrbuch für Geologie und Paläontologie, Abhandlungen, 246, 1-35.

SIMMS, M. J. and RUFFELL, A. H. 1990. Climatic and biotic change in the late Triassic. Journal of the Geological Society, 147, 321-327.

SMALL, B. J. 1985. The Triassic thecodontian reptile Desmatosuchus: osteology and relationships. Unpublished Master's thesis, Texas Tech University, Lubbock, Texas, USA, 83 pp.

- 2002. Cranial anatomy of Desmatosuchus haplocerus (Reptilia: Archosauria: Stagonolepididae). Zoological Journal of the Linnean Society, 136: 97-111. 
898 SULEJ, T. 2002. Species discrimination of the Late Triassic temnospondyl amphibian 899 Metoposaurus diagnosticus. Acta Palaeontologica Polonica, 47, 535-546.

900 -2005. A new rauisuchian reptile (Diapsida: Archosauria) from the Late Triassic of Poland. $901 \quad$ Journal of Vertebrate Paleontology, 25, 78-86.

902 - 2007. Osteology, variability, and evolution of Metoposaurus, a temnospondyl from the Late 903 Triassic of Poland. Palaeontologia Polonica, 64, 29-139.

$904-2010$. The skull of an early Late Triassic aetosaur and the evolution of the stagonolepidid 905 archosaurian reptiles. Zoological Journal of the Linnean Society, 158: 860-881.

906 - and MAYER, D. 2005. The temnospondyl amphibian Cyclotosaurus from the Upper Triassic 907 of Poland. Palaeontology, 48, 157-170.

908 - NIEDŹWIEDZKI, G. and BRONOWICZ, R. 2012. A new Late Triassic vertebrate fauna 909 from Poland with turtles, aetosaurs, and coelophysoid dinosaurs. Journal of Vertebrate $910 \quad$ Paleontology, 32, 1033-1041.

911 - BRONOWICZ, R., TAŁANDA, M. and NIEDŹWIEDZKI, G. 2011. A new dicynodont912 archosaur assemblage from the Late Triassic (Carnian) of Poland. Earth and 913 Environmental Science Transactions of the Royal Society of Edinburgh, 101, 261-269.

914 SZARSKI, H. (ed.) GRODZIŃSKI, Z., JASIŃSKI A., and ORSKA, J. 1976. Anatomia 915 porównawcza kręgowców. Państwowe Wydawnictwo Naukowe, Warszawa. 773 pp. 
916 SZCZYGIELSKI, T. 2017. Homeotic shift at the dawn of the turtle evolution. Royal Society $917 \quad$ Open Science, 4, 160933.

918 - and SULEJ, T. 2016. Revision of the Triassic European turtles Proterochersis and 919 Murrhardtia (Reptilia, Testudinata, Proterochersidae), with the description of new taxa 920 from Poland and Germany. Zoological Journal of the Linnean Society, 177, 395-427.

921 SZULC, J. 2005. Sedimentary environments of the vertebrate-bearing Norian deposits from 922 Krasiejów, Upper Silesia (Poland). Hallesches Jahrbuch für Geowissenschaften, Reihe B, 923 Beiheft, 19, 161-170.

924 - 2007. Krasiejów - inactive clay pit and tetrapod exposition. In Szulc, J. and Becker, A. (eds) 925 International Workshop on the Triassic of Southern Poland. Polish Geological Institute 926 and Institute of Geological Sciences, Jagiellonian University, Kraków, pp. 53-55.

927 - RACKI, G. and JEWUŁA, K. 2015. Key aspects of the stratigraphy of the Upper Silesian 928 middle Keuper, southern Poland. Annales Societatis Geologorum Poloniae, 85, 557-586.

TALMAGE, R. V. and BUCHANAN, G. D. 1954. The armadillo: a review of its natural history, ecology, anatomy and reproductive physiology. The Rice Institute Pamphlet, Monograph in Biology, Vol. 41, No. 2. The Rice Institute, Houston, Texas, USA. 135 pp.

WALKER, A. D. 1961. Triassic reptiles from the Elgin area: Stagonolepis, Dasygnathus and their allies. Philosophical Transactions of the Royal Society B: Biological Sciences, 244, $103-204$. 
935 WANG, B., YANG, W., SHERMAN, V. R. and MEYERS, M. A. 2016. Pangolin armor:

936 overlapping, structure, and mechanical properties of the keratinous scales. Acta

937 biomaterialia, 41, 60-74.

938 WU, C. 2011. VisualSFM: A visual structure from motion system. [WWW document].

939 http://ccwu.me/vsfm/.

940 VON BACZKO, M.B. and EZCURRA, M. D. 2013. Ornithosuchidae: a group of Triassic

941 archosaurs with a unique ankle joint. In NESBITT, S. J., DESOJO, J. B. and IRMIS, R.B.

942 (eds) 2013. Anatomy, Phylogeny and Palaeobiology of Early Archosaurs and their Kin.

943 Geological Society, London, Special Publications, 379, 187-202.

944 WEINBAUM, J.C. 2013. Postcranial skeleton of Postosuchus kirkpatricki (Archosauria:

945 Paracrocodylomorpha), from the upper Triassic of the United States. In NESBITT, S. J.,

946 DESOJO, J. B. AND IRMIS, R. B. (eds) 2013. Anatomy, Phylogeny and Palaeobiology of

947 Early Archosaurs and their Kin. Geological Society, London, Special Publications, 379,

$948 \quad 525-553$.

949 YANG, W., CHEN, I. H., GLUDOVATZ, B., ZIMMERMANN, E. A., RITCHIE, R. O. and

950 MEYERS, M. A. 2013. Natural flexible dermal armor. Advanced Materials, 25, 31-48.

951 ZATOŃ, M., PIECHOTA, A. and SIENKIEWICZ, E. 2005. Late Triassic charophytes around

952 the bone-bearing bed at Krasiejów (SW Poland) - palaeoecological and environmental

953 remarks. Acta Geologica Polonica, 55, 283-293. 
Figure 1

Reconstruction of the right humerus of the aetosaur Stagonolepis olenkae, Sulej 2010.

(A) Ventral view. (B) Dorsal view. (C) Lateral view. (D) Medial view. (E) Proximal view. (F) Distal view. Symbols attached to pictures show which surface is exposed in the drawing, with (X) for the dorsal, ( $\mathbf{A})$ for the ventral, ( $\boldsymbol{(})$ for the medial, and (0) for the lateral, and how the surfaces are oriented in proximal and distal view. Scale based on spec. ZPAL AbIII/1175.

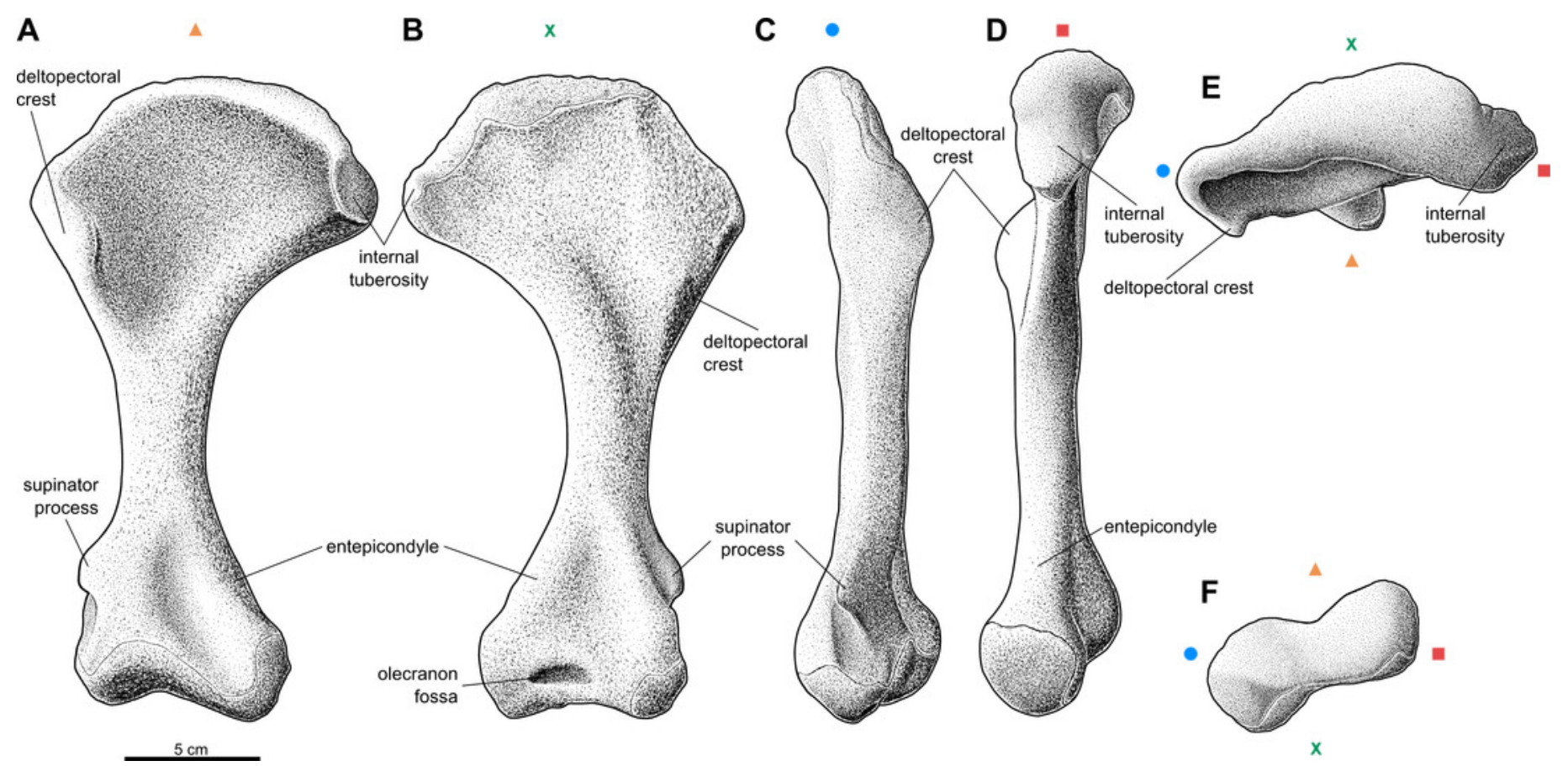


Figure 2

Forearm of the aetosaur Stagonolepis olenkae, Sulej 2010.

(A) Photograph and (B) schematic drawing of the specimen ZPAL AbIlI/2407 with the forearm bones in medial view and (C, D) in dorsal view. (E) Reconstruction of the forearm bones in dorsal view. In the schematic drawings osteoderms are marked red and the sediment is marked grey. All photographs and drawings are in the same scale.
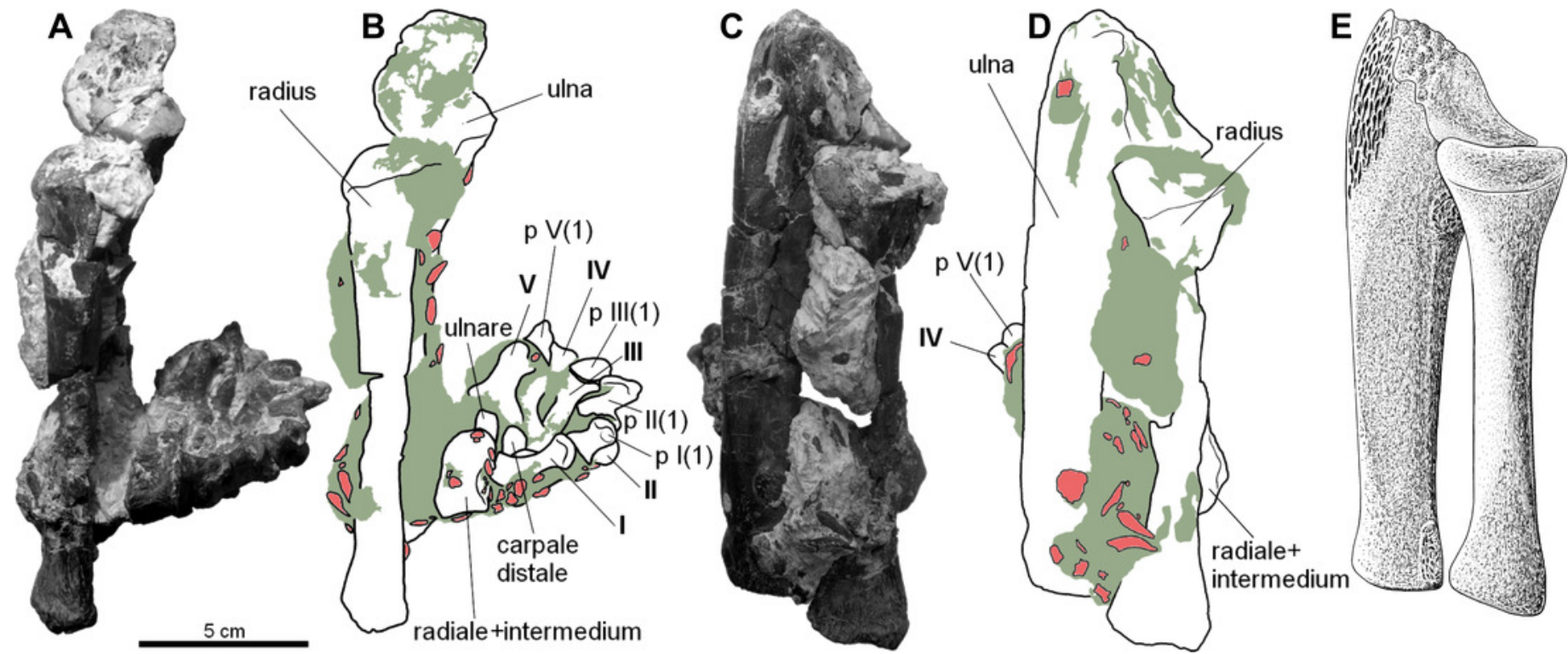
Figure 3

Reconstruction of the left ulna of the aetosaur Stagonolepis olenkae, Sulej 2010.

(A) Dorsal view. (B) Ventral view. (C) Medial view. (D) Lateral view. (E) Proximal view. (F) Distal view. Symbols attached to pictures show which surface is exposed in the drawing, with $(\mathbf{X})$ for the dorsal, ( $\mathbf{A})$ for the ventral, ( $\mathbf{\square})$ for the medial, and $(\boldsymbol{Q})$ for the lateral, and how the surfaces are oriented in proximal and distal view. Scale based on spec. ZPAL AbIII/3351.

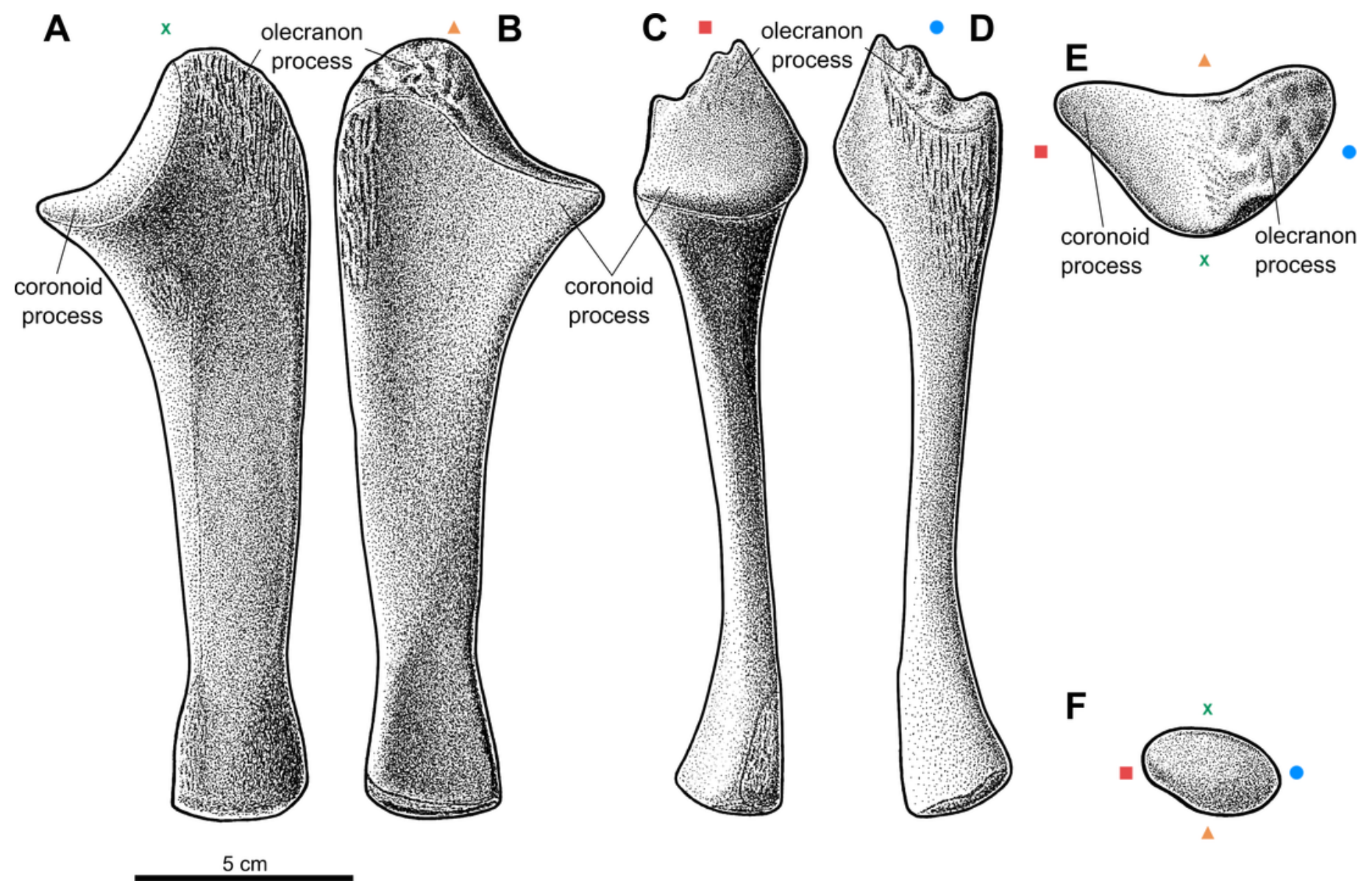


Figure 4

Reconstruction of the left radius of the aetosaur Stagonolepis olenkae, Sulej 2010.

A) Dorsal view. (B) Ventral view. (C) Medial view. (D) Lateral view. (E) Proximal view. (F)

Distal view. Symbols attached to pictures show which surface is exposed in the drawing, with

(X) for the dorsal, ( $\mathbf{(})$ for the ventral, ( $\mathbf{\square})$ for the medial, and $(\boldsymbol{O})$ for the lateral, and how the surfaces are oriented in proximal and distal view. Scale based on spec. ZPAL AbIII/3322.w
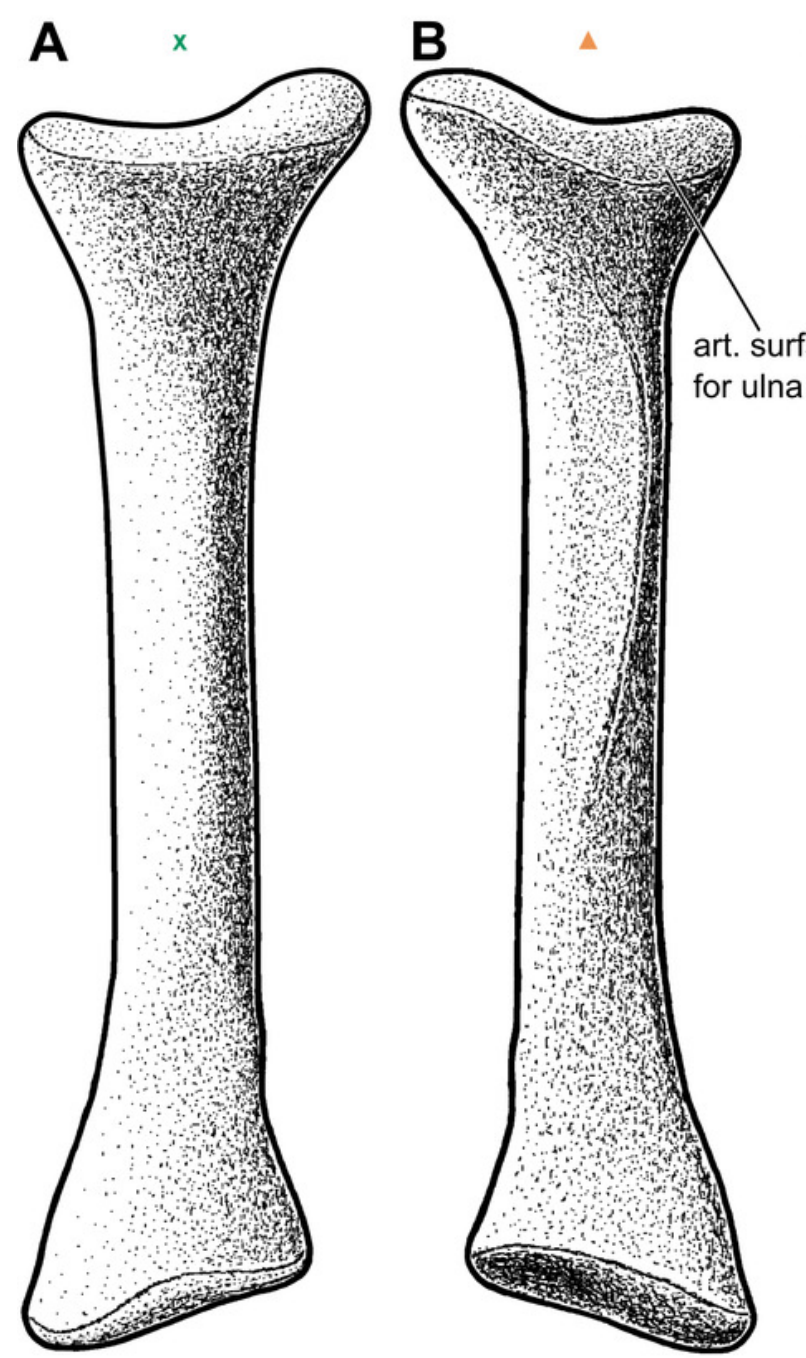

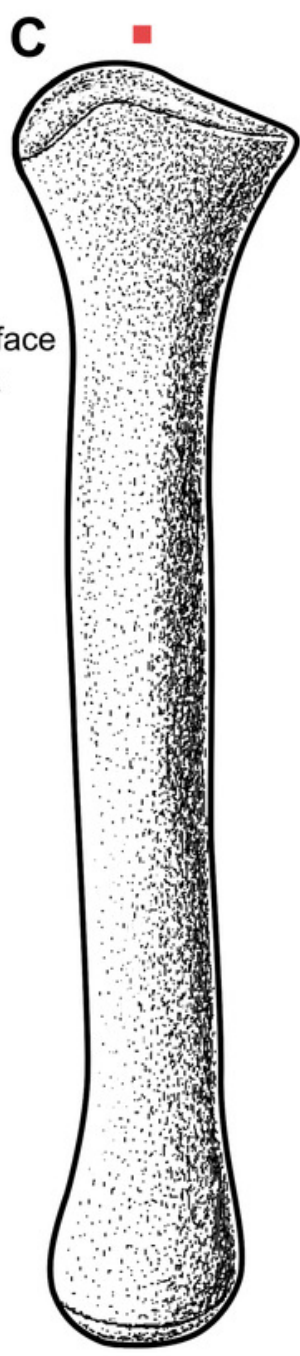

art. surface for ulna

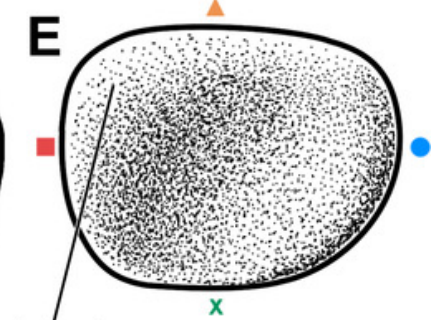

art. surface

for ulna
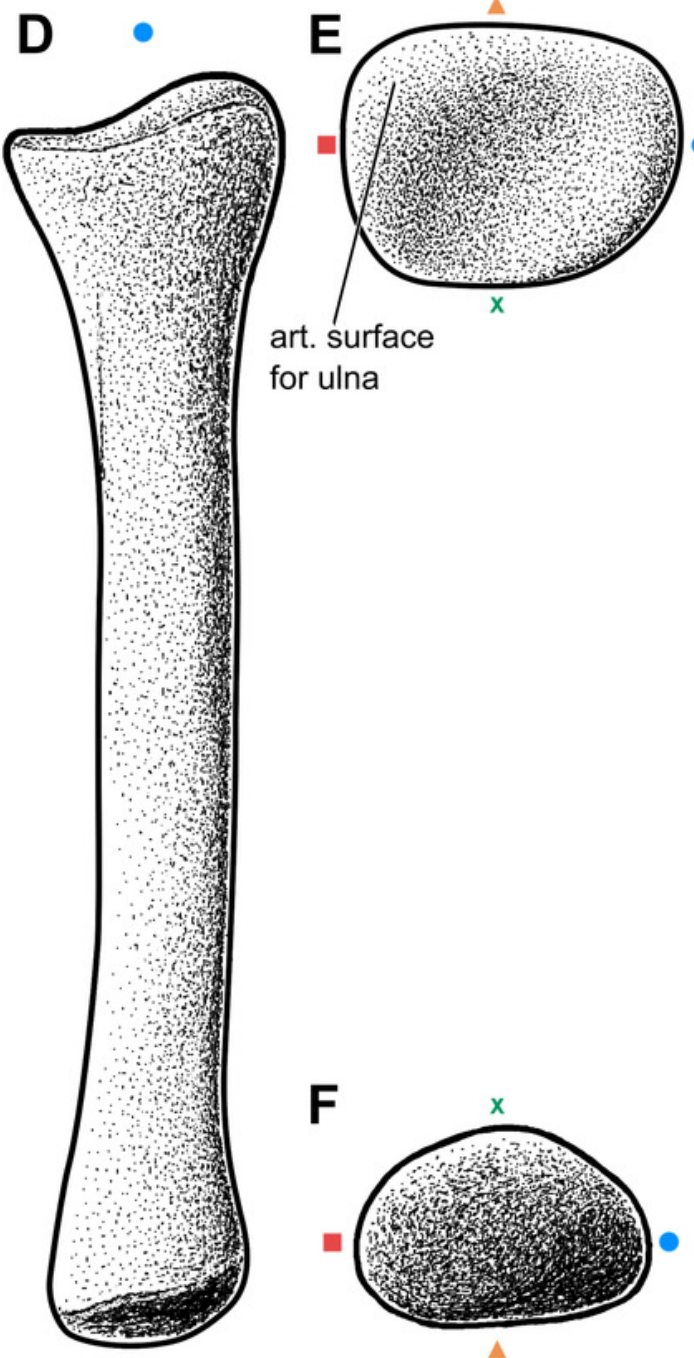


\section{Figure 5}

The largest carpal bone of the aetosaur Stagonolepis olenkae, Sulej 2010. Probably fused radiale and intermedium.

(A-F) Photographs of the left bone, spec. ZPAL AbIII/2071. (G-L) Photographs of the right bone, spec. ZPAL AbIII/2071. (M-S) Reconstruction of the right bone. (A,G,M) Proximal view. $(B, H, N)$ Distal view. $(C, I, O)$ Medial view. $(D, J, P)$ Lateral view. $(E, K, R)$ Dorsal view. $(F, L, S)$ Ventral view. Symbols attached to pictures show which surface is exposed in the drawing or photograph, with $(+)$ for the proximal, $(*)$ for the distal, $(\boldsymbol{\square})$ for the medial, and $(\mathbf{O})$ for the lateral, and how the surfaces are oriented in dorsal and ventral view. All phothographs and drawings are in the same scale.
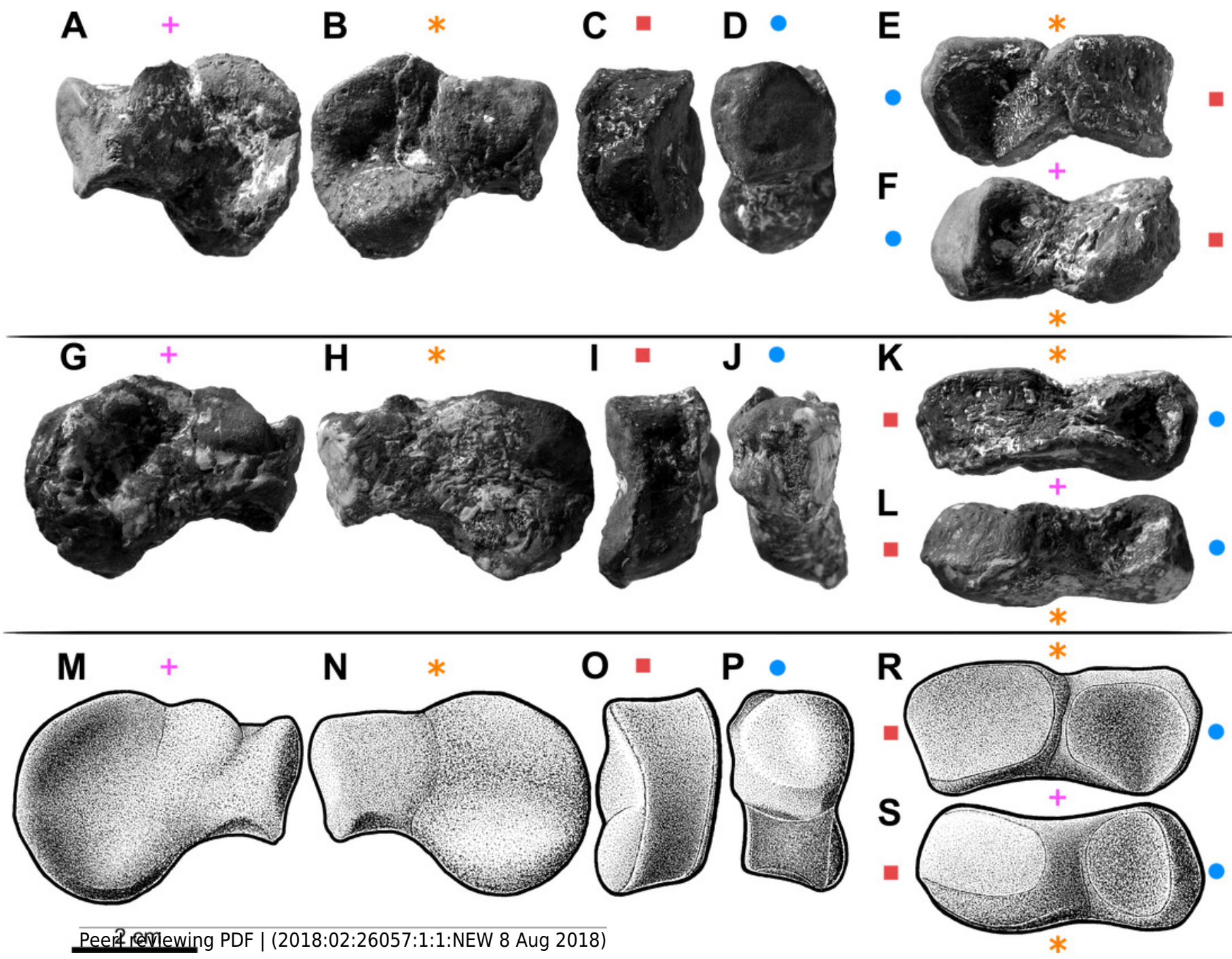


\section{Figure 6}

Manus of the aetosaur Stagonolepis olenkae, Sulej 2010.

(A) Photograph and (B) schematic drawing of the right manus spec. ZPAL AbIII/3349/1 in dorsal and (C, D) ventral view. (E) Reconstruction of the right carpus and manus in dorsal view. (F) Hypothetical arrangement of osteoderms in dorsal view. In the schematic drawings osteoderms are marked red and the sediment is marked grey. Photographs and drawings A-D are in the same scale. Restoration (E) of the carpus and manus is based mostly on spec. ZPAL AbIII/3349/1 and 2071.

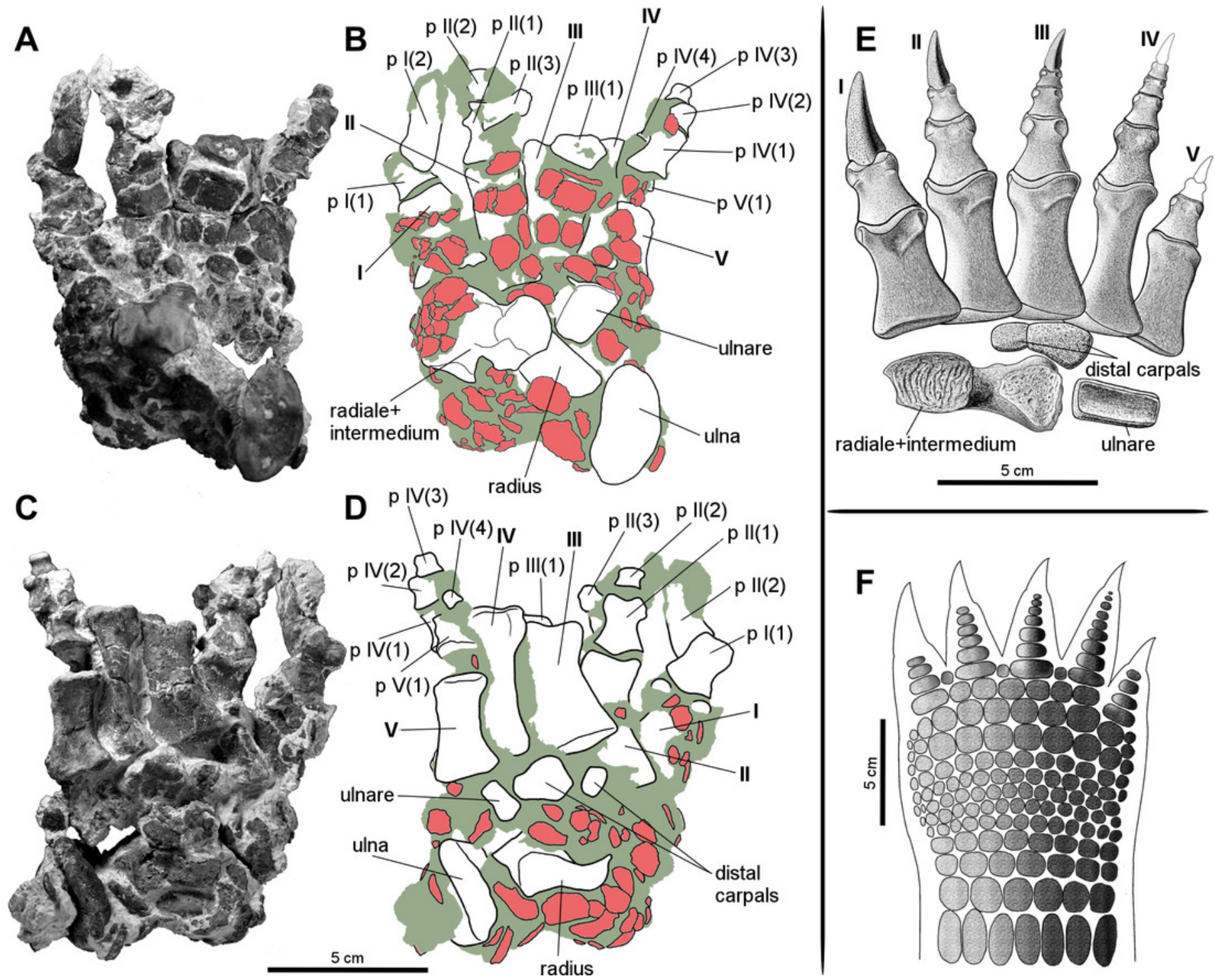

